\title{
Petrology of parasitic and eccentric cones on the flanks and base of Somma-Vesuvius
}

\author{
Ray Macdonald ${ }^{1,2}$ • Boguslaw Bagiński ${ }^{1}$ - Giuseppe Rolandi ${ }^{3} \cdot$ Benedetto De Vivo $^{3}$. \\ Anna Kopczyńska ${ }^{1}$
}

Received: 9 June 2015 / Accepted: 11 November 2015 /Published online: 9 December 2015

(C) The Author(s) 2015. This article is published with open access at Springerlink.com

\begin{abstract}
Parasitic and eccentric cones on the flanks and at the base of Somma-Vesuvius potentially provide information on the plumbing system of the complex. We present geochemical data for minerals, glasses and rocks from the Pollena and Cercola cones. The rocks are phonotephrites and a basaltic trachyandesite. A volumetrically dominant type contains phenocrysts of olivine, clinopyroxene, leucite, plagioclase \pm apatite $\pm \mathrm{Fe}$-Ti-oxides. A second type is phlogopite-phyric. Low magnesium-numbers (62-49) and $\mathrm{Ni}$ abundances $(\leq 32 \mathrm{ppm})$ indicate that the primary magmas underwent crustal-level fractionation but the cores of olivine and clinopyroxene phenocrysts carry records of the parental magmas. Geochemical data indicate that the rocks form more than one magmatic lineage. Matrix glasses point to low-pressure fractionation trends towards decreasing melt silica-undersaturation. The phlogopitephyric rocks were derived from more hydrous magmas than those lacking phlogopite phenocrysts, perhaps at higher pressures. Phenocryst assemblages are difficult to reconcile with published experimental work and it is likely that they are far from equilibrium assemblages. The cone
\end{abstract}

\section{Editorial handling: L. Nasdala}

Electronic supplementary material The online version of this article (doi:10.1007/s00710-015-0410-6) contains supplementary material, which is available to authorized users.

Ray Macdonald

r.macdonald@lancaster.ac.uk

1 IGMiP Faculty of Geology, University of Warsaw, al. Żwirki i Wigury 93, 02-089 Warszawa, Poland

2 Environment Centre, Lancaster University, Lancaster LA1 4YQ, UK

3 Dipartimento di Scienze della Terra, dell'Ambiente e delle Risorse, Università di Napoli Federico II, 80134 Naples, Italy magmas were probably derived from high levels within the main plumbing system via lateral transport.

\section{Introduction}

Despite being arguably the most intensively studied volcanic complex in the world, many aspects of the evolution of Somma-Vesuvius remain enigmatic. For example, it is not known in detail whether the volcano's plumbing system involves a single, high-level or deeper-level reservoir, or is a long narrow vertical chamber with several potential small reservoirs (Belkin et al. 1985; Belkin and De Vivo 1993; Lima et al. 2003). It is uncertain how long-lived these reservoirs might be or how persistent they may be in time and space. Yet this information is critical to understanding and predicting the volcano's behaviour. Here we explore the information available from a series of small centres on the flanks of the complex. The cones occur up to $10 \mathrm{~km}$ from the centre of the Somma caldera and thus are very unlikely to underlie directly any part of the plumbing system as currently modelled geophysically and petrologically. It seems possible, therefore, that they hold a record of the primary magmas feeding Vesuvius and of the history of magmatic evolution in the deeper parts of the system. The petrology and geochemistry of the cones have the potential to help characterize the transition from the stratovolcano-building phase (39-25 ka; Santacroce 1987). Our specific aims are to (i) list the occurrences of the cones; (ii) provide new mineral chemical and geochemical data for them. Rocks of this age have not been characterized in detail because they are usually covered in the field by younger deposits (Santacroce and Sbrana 2003; Piochi et al. 2006; De Vivo et al. 2010); (iii) to outline the $P-T-f \mathrm{O}_{2}$ conditions under which the magmas evolved on the basis of petrological information and published phase equilibrium studies; and (iv) to 
assess the significance of the new data for the plumbing system of Somma-Vesuvius.

\section{General geology}

The Somma-Vesuvius volcanic complex is located at the south-west margin of the Campanian Plain which is a downfaulted, graben-like structure, filled with Quaternary pyroclastic deposits and bordered on the east sector by the Mesozoic Apennine carbonate platform (Ippolito et al. 1975; Schettino and Turco 2006). The subsidence was controlled by a fault system with Plio-Pleistocene NE-SW and NW-SE trends. Since early Somma lava flows were emplaced above the 39 ka Campanian Ignimbrite (Brocchini et al. 2001), and the first plinian eruption of Codola at $\sim 33 \mathrm{ka}$ (Giaccio et al. 2008), we assume that the Somma volcano was built up, to a height of more than $2000 \mathrm{~m}$, in the age range 39-25 ka (Cioni et al. 1999; Santacroce et al. 2008). The flanks of this volcano are known to contain sets of aligned parasitic cones at different altitudes, possibly derived from a lateral branch of the main eruptive conduit (Santacroce and Sbrana 2003). Small centres termed eccentric cones are formed at the base of the volcano. The cones are aligned parallel to the two regional stress directions. Other minor centres appear, however, to have been controlled by local stress conditions (e.g., Acocella et al. 2006).

One alignment of eruptive vents extends on the northern flank of Somma between the towns of Volla and Pollena (Fig. 1) and consists of an eccentric volcanic vent at Cercola and the Pollena parasitic cones. These bodies were formed during the final stages of Somma growth along fractures associated with the main conduit (the Pollena parasitic cones on the north side of Somma), or along fractures associated with a branch point which is a new eruptive conduit system (the Cercola eccentric cone). The Pollena cones point to flank activity on Somma during its growth between 250 and $300 \mathrm{~m}$ asl. The volcanic activity comprised weak explosions accompanied by effusive activity in the intermediate and closing
Fig. 1 Location of eccentric and parasitic cones on the flanks and base of Somma-Vesuvius

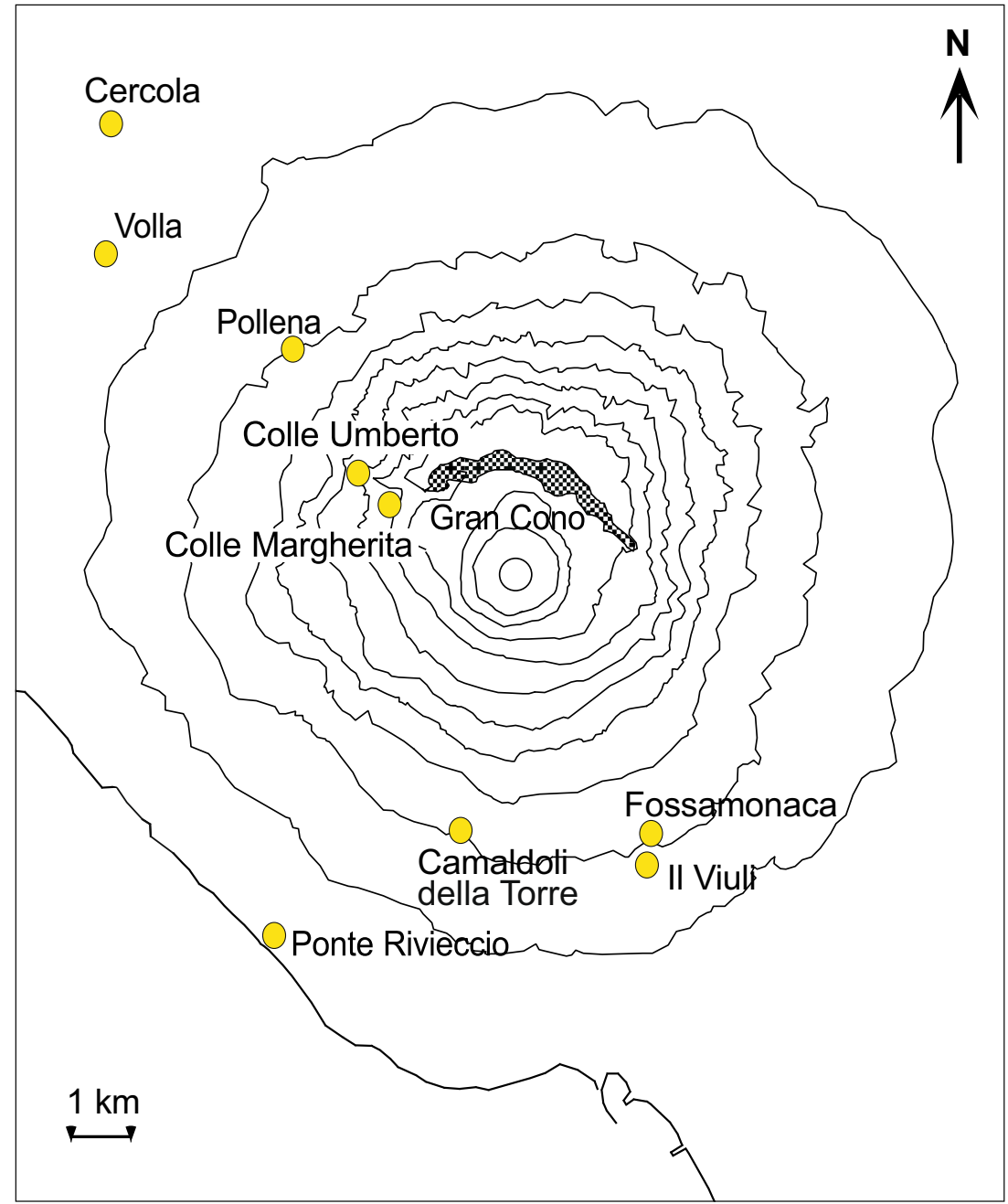


phases. The Cercola cone is largely buried beneath more recent pyroclastic eruptions and alluvial deposits. Its volcanic nature is similar to the Pollena edifices, but it is larger. From stratigraphic relationships, it has been deduced that the age of these two groups of volcanic structures is certainly older than 20,000 years and thus overlaps the period of construction of the Somma stratovolcano (39-25 ka).

A second group of cones extends from that at Camaldoli della Torre at Torre del Greco, to the system of cones present on the eastern slopes of Somma, at Ottaviano (Fig. 1). The Camaldoli della Torre cone is located on the southern side of the Somma structure, at an altitude of $\sim 150-200 \mathrm{~m}$ asl. Its original structure is preserved only on its north-eastern side, on which the Camaldoli monastery is located. The age of this centre is rather recent, being covered by the products of the AD79 eruption. It was probably built during the interplinian phase of the protohistoric period (Rolandi et al. 1998; Di Renzo et al. 2007). This vent is aligned with a small contemporaneous vent close to the coast near Ponte Rivieccio at Torre del Greco.

The small Viulo and Fossa Monaca eruptive cones, belonging to the mediaeval interplinian phase (Rolandi et al. 1998) when the Vesuvius cone was being constructed (AD 4721139), are located on the southern slope of Somma. Eccentric vents of the recent-historical interplinian phase are aligned on a fracture associated with the paroxysmal effusive phase of the 1760 eruption, and on those opened up on the southern slope of Vesuvius during the paroxysmal phase of 1906, between 700 and $800 \mathrm{~m}$ asl. Noteworthy also is the eccentric activity identified in the domes of "Colle Margherita" in 1895 (partly buried by the lava eruption of 1944), and "Colle Umberto" in 1898, both belonging to the same Vesuvian cycle of 1872-1906.

\section{Samples and analytical methods}

This study has focussed on the Cercola eccentric cone and on the Pollena parasitic cones, which are well exposed in the Pollena quarry. Lava and scoria samples were taken from three Pollena cones; details of sampling sites are given in the Appendix. We have also used a sample from the Cercola cone, which is well defined in its shape but poorly exposed, being known only from boreholes. Phenocryst and matrix glass analyses were made using a CAMECA SX100 electron microprobe at the Inter-Institute Analytical Complex for Minerals and Synthetic Substances of Warsaw University in wavelength dispersive mode. Accelerating voltage was $15 \mathrm{keV}$, beam current $20 \mathrm{nA}$ and beam diameter $1-20 \mu \mathrm{m}$. The counting time for most elements was $20 \mathrm{~s}$ at peak and $10 \mathrm{~s}$ at background. Sodium was analysed first, with a beam current close to $10 \mathrm{nA}$ and a broader beam diameter (up to $20 \mu \mathrm{m}$ ). Natural minerals and synthetic multicomponent materials were used as calibration standards: albite $(\mathrm{Na})$, orthoclase $(\mathrm{K}, \mathrm{Al})$, diopside $(\mathrm{Si}, \mathrm{Mg})$, wollastonite $(\mathrm{Ca})$, rhodonite $(\mathrm{Mn})$, barite $(\mathrm{Ba})$, chromite $(\mathrm{Cr})$, rutile $(\mathrm{Ti})$, hematite $(\mathrm{Fe})$, synthetic $\mathrm{NiO}$ $(\mathrm{Ni})$, tugtupite $(\mathrm{Cl})$, and synthetic $\mathrm{V}_{2} \mathrm{O}_{5}(\mathrm{~V})$. Apatite was analysed using the conditions outlined in Macdonald et al. (2013). Corrections for atomic number, absorption and fluorescence were accomplished using the PAP procedure (Pouchou and Pichoir 1991). Detection limits for most major elements were close to $0.01 \mathrm{wt} . \%$, except for Ti and Mn where the limits varied in the range $0.02-0.04$ wt.\%. Representative mineral and glass analyses are presented in Tables 2, 3, 4, 5, and 7. The full data set may be found in Supplementary Tables 1-5.

Whole-rock analyses (Table 6) were made at ACME Analytical Laboratories Ltd, Canada. Major elements (and $\mathrm{Cr}$ ) were determined by ICP-ES and trace elements by ICP-MS. Mean detection limits of major elements were close to $0.1 \mathrm{wt} . \%$ and for the trace elements from 0.01 to $0.1 \mathrm{ppm}$.

\section{Petrography}

Two types can be distinguished petrographically (Table 1). The dominant type (all from the Pollena cones) has the phenocryst assemblage olivine (ol) - clinopyroxene (cpx) - leucite (lct) - plagioclase (pl) \pm apatite (ap) \pm Fe-Ti-oxides (ox). The second type contains phlogopite (phl) phenocrysts, along with $\mathrm{ol}+\mathrm{cpx}+\mathrm{ox} \pm \mathrm{pl} \pm \mathrm{lct}+\mathrm{ap}$.

Type 1 samples are vesicular, with up to $20 \%$ vesicles in the lavas and $70 \%$ in the scoria. Modal phenocryst abundances are up to $30 \%$, with clinopyroxene the dominant phase. There is a notable tendency for the phenocrysts to cluster, in either monomineralic or polymineralic aggregates. Clinopyroxene phenocrysts are pale brown, euhedral to subhedral, and up to $4 \mathrm{~mm}$ across. Zoning is almost ubiquitous, with normal, reverse, oscillatory and sector forms. As discussed below, some crystals show complex interplays of crystallization and resorption. Inclusions of olivine, leucite, apatite and glass are common, Fe-Tioxide inclusions less common. Olivine occurs mainly as subhedral prisms, $\leq 1 \mathrm{~mm}$ in size, either as discrete crystals or included in clinopyroxene (Fig. 2a). It forms large, partially resorbed crystals in sample L1e (Fig. 2b). It occasionally shows oscillatory zoning. Leucite phenocrysts are up to $3 \mathrm{~mm}$ across, euhedral to subhedral in form and commonly occurring in clusters. In L1, they are zoned and partially resorbed. Leucite also forms strings of inclusions close to the rims of clinopyroxene phenocrysts, especially in sample L3.

Plagioclase microphenocrysts, $\leq 1 \mathrm{~mm}$, occur mainly as clusters of laths, often stellate, but also form discrete crystals (Figs. 2c, d). Some crystals are zoned to lighter rims. Apatite has been identified in six samples (Table 1), usually included 
Table 1 Phenocryst assemblages and compositions

\begin{tabular}{|c|c|c|c|c|c|c|c|c|}
\hline Sample & $T A S^{*}$ & $M g \#$ & Phenocryst assemblage & $\begin{array}{l}\text { Olivine } \\
\mathrm{Mg} \#\end{array}$ & $\begin{array}{l}\text { Cpx } \\
\mathrm{Mg} \#\end{array}$ & $\begin{array}{l}\text { Leucite } \\
\mathrm{K} /(\mathrm{K}+\mathrm{Na})\end{array}$ & $\begin{array}{l}\text { Plagioclase } \\
\text { An (mol.\%) }\end{array}$ & $\begin{array}{l}\text { Phlogopite } \\
\mathrm{Mg \#}\end{array}$ \\
\hline Volbisa & - & - & $\mathrm{ol}+\mathrm{cpx}+\mathrm{lct}+\mathrm{pl}+\mathrm{ap}$ & & & & & \\
\hline Volbisb & bta & 63 & $\mathrm{ol}+\mathrm{cpx}+\mathrm{lct}+\mathrm{pl}+\mathrm{ap}$ & $72-75$ & $75-80$ & $0.94-1.00$ & $71-84$ & - \\
\hline Volbisd & bta & 62 & $\mathrm{ol}+\mathrm{cpx}+\mathrm{lct}+\mathrm{pl}+\mathrm{ox}$ & & & & & \\
\hline Volbise & - & - & $\mathrm{ol}+\mathrm{cpx}+\mathrm{lct}+\mathrm{pl}$ & & & & & \\
\hline L1e & $\mathrm{pt}$ & 59 & $\mathrm{ol}+\mathrm{cpx}+\mathrm{lct}+\mathrm{pl}+\mathrm{ap}+\mathrm{ox} ?$ & $60-89$ & $74-85$ & $0.96-0.96$ & $64-88$ & - \\
\hline $\mathrm{L} 2 \mathrm{~h}$ & bta & 48 & $\mathrm{ol}+\mathrm{cpx}+\mathrm{pl}+\mathrm{phl}+\mathrm{ap}+\mathrm{ox}$ & $66-74$ & $53-90$ & - & $54-94$ & $63-75$ \\
\hline Vo2f & $\mathrm{pt} / \mathrm{bta}$ & 60 & $\mathrm{ol}+\mathrm{cpx}+\mathrm{lct}+\mathrm{pl}$ & $74-75$ & $73-85$ & $0.95-0.99$ & $70-82$ & - \\
\hline Vo2g & - & - & $\mathrm{ol}+\mathrm{cpx}+\mathrm{lct}+\mathrm{pl}$ & & & & & \\
\hline V1 & $\mathrm{pt}$ & 60 & $\mathrm{ol}+\mathrm{cpx}+\mathrm{lct}+\mathrm{pl}$ & $73-75$ & $74-87$ & $0.96-0.99$ & $75-86$ & - \\
\hline V3 & bta & 62 & $\mathrm{ol}+\mathrm{cpx}+\mathrm{lct}+\mathrm{pl}+\mathrm{ap}$ & $75-78$ & $76-81$ & $0.98-0.99$ & $61-78$ & - \\
\hline L1 & $\mathrm{pt}$ & 53 & $\mathrm{ol}+\mathrm{cpx}+\mathrm{lct}+\mathrm{pl}+\mathrm{ox}$ & $46-77$ & $71-82$ & $0.99-1.00$ & $63-90$ & - \\
\hline L3 & $\mathrm{pt} / \mathrm{bta}$ & 61 & $\mathrm{ol}+\mathrm{cpx}+\mathrm{pl}$ & $72-75$ & $70-83$ & - & $33-82$ & - \\
\hline VX & $\mathrm{pt}$ & 49 & $\mathrm{ol}+\mathrm{cpx}+\mathrm{phl}+\mathrm{ox}+\mathrm{ap}+\mathrm{lct}$ & $72-75$ & $56-89$ & $0.97-0.98$ & - & $73-77$ \\
\hline
\end{tabular}

TAS, classification in the total alkalis-silica scheme (Le Bas et al. 1986). bta, basaltic trachyandesite; pt, phonotephrite. -, not determined. Mg\#, magnesium-number $=100 *\left(\mathrm{Mg} /\left(\mathrm{Mg}+\mathrm{Fe}^{2+}\right)\right)$. Ol, olivine, cpx, clinopyroxene, lct, leucite, pl, plagioclase, phl, phlogopite, ap, apatite, ox, FeTi-oxides

Fig. 2 BSE images of selected textural relationships in the phenocrysts. a Partly resorbed clinopyroxene (Cpx) phenocrysts, in contact along the dashed line, with inclusions of olivine (Ol) and plagioclase (Pl). Sample Volbisb. b Large olivine phenocryst in sample L1. A compositional profile has been drawn across the marked line $a-b$ (see text for details). c Zoned plagioclase phenocryst in sample Volbisb. Compositional variation (expressed as mol\% An) along the profile $a-b$ is shown under the image. d Partly resorbed, oscillatory-zoned plagioclase phenocryst in sample L1. Compositional variation (expressed as $\mathrm{mol} \% \mathrm{An}$ ) along the profile $a-b$ is shown under the image. Small phlogopite (Phl) needles occur in a vesicle at top-left
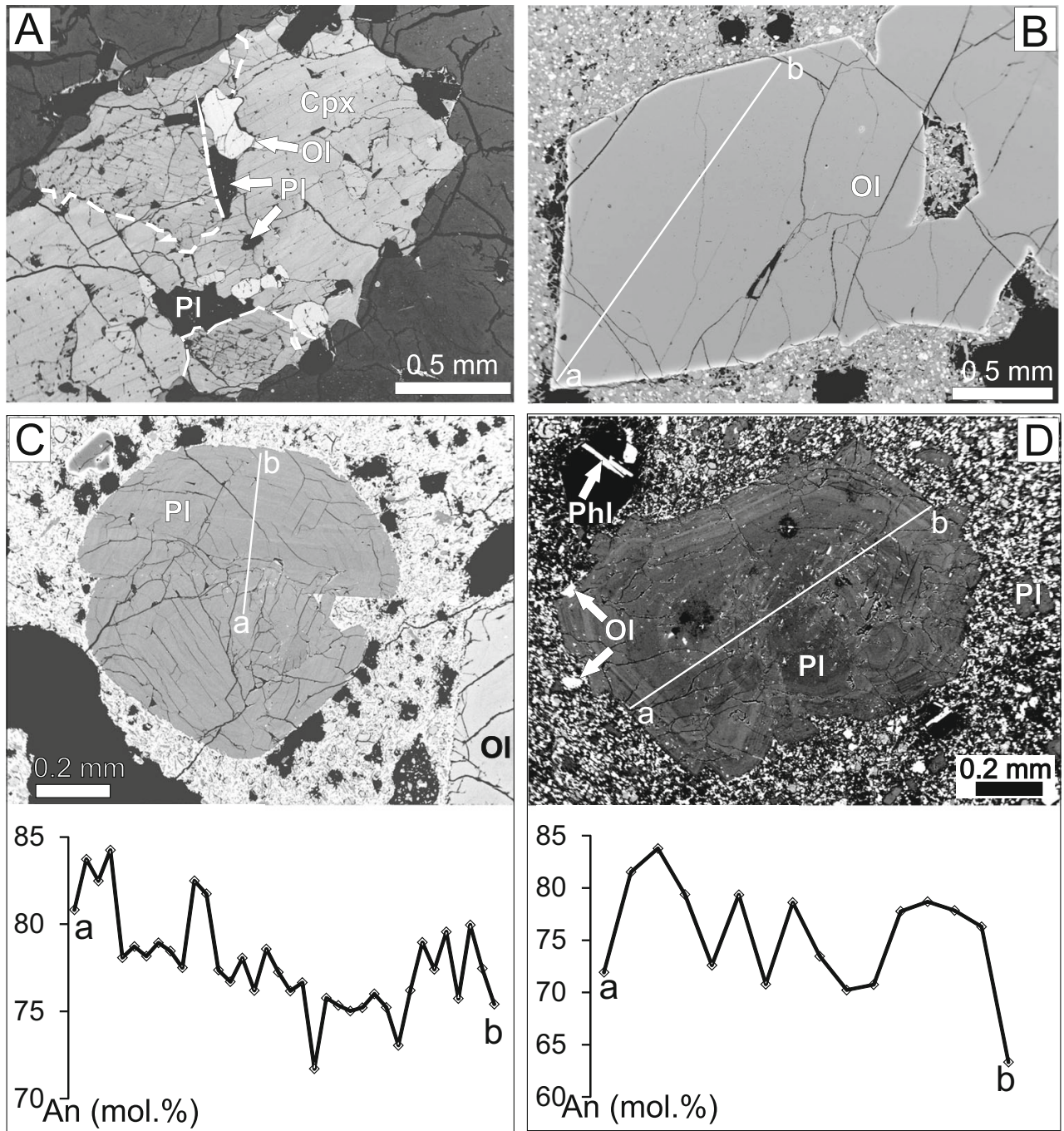
in clinopyroxene. Oxide crystals large enough to be considered microphenocrysts $(\leq 70 \mu \mathrm{m})$ or as inclusions in other phenocrysts occur in four, and possibly a fifth, rock. The order of crystallization of the phenocrysts, as deduced from phenocryst assemblages and inclusion relationships, was olivine clinopyroxene - leucite - plagioclase - apatite - oxides.

The matrix in Type 1 rocks varies mainly in the proportion of glass to crystals. Glass, from pale to dark brown in colour, occurs (i) as the dominant matrix material, (ii) as interstitial pools in the matrix, (iii) in interstices in phenocryst clusters, and (iv) as inclusions in clinopyroxene and leucite phenocrysts. In sample L3 the glass is completely devitrified. The mineral phases are clinopyroxene, plagioclase, leucite and FeTi-oxides, with minor amounts of phlogopite. An unusual feature in sample Volbise comprises coalescing sub-rounded patches, up to $\sim 600 \mu \mathrm{m}$ across, with a symplectite-like texture (Fig. 3a, b). The example in Fig. 3a contains an intergrowth of a highly magnesian olivine ( $\mathrm{Fo}_{97}$; darker) and a more Fe-rich olivine $\left(\mathrm{Fo}_{76}\right.$; lighter), with three areas of glass charged with Fe-Ti-oxide crystals. The patches are associated with vesicles - note the ring of vesicles in Fig. $3 \mathrm{a}$ - and it is possible that the intergrowths formed as quench products during degassing of the host magma. The crystal form of the individual units in the patches may suggest that the patches were originally olivine cumulates, from deeper in the plumbing system.

The phlogopite phenocrysts in Type 2 samples (VX, L2h) occur as elongated red plates, up to $1.1 \mathrm{~mm}$ long, in some cases partly to almost completely replaced by opacitic material, presumably formed by water loss during magma ascent (Figs. 3c, d). Euhedral to subhedral crystals of clinopyroxene up to $2 \mathrm{~mm}$ across are complexly zoned (see below). FeTioxides form small equant grains, $0.2-0.3 \mathrm{~mm}$ across, either as discrete crystals or included in clinopyroxene. The olivine phenocrysts are less common and smaller $(<0.5 \mathrm{~mm})$ than in Type 1 rocks and show variable degrees of resorption. Leucite occurs as microphenocrysts $(<0.5 \mathrm{~mm})$ in sample VX and is absent from L2h. Acicular apatite forms common inclusions in clinopyroxene. The intergrowth of the mica with clinopyroxene phenocrysts (Fig.3b) indicates that it appeared early in the crystallization sequence. Matrix glass in sample VX occurs mainly as patchy rims around phenocrysts.

Glass (melt) inclusions in both types occur most commonly in clinopyroxene and leucite phenocrysts, often rimming olivine and plagioclase inclusions. They range in size up to $100 \mu \mathrm{m}$ and in shape from rounded to elongate to irregular.
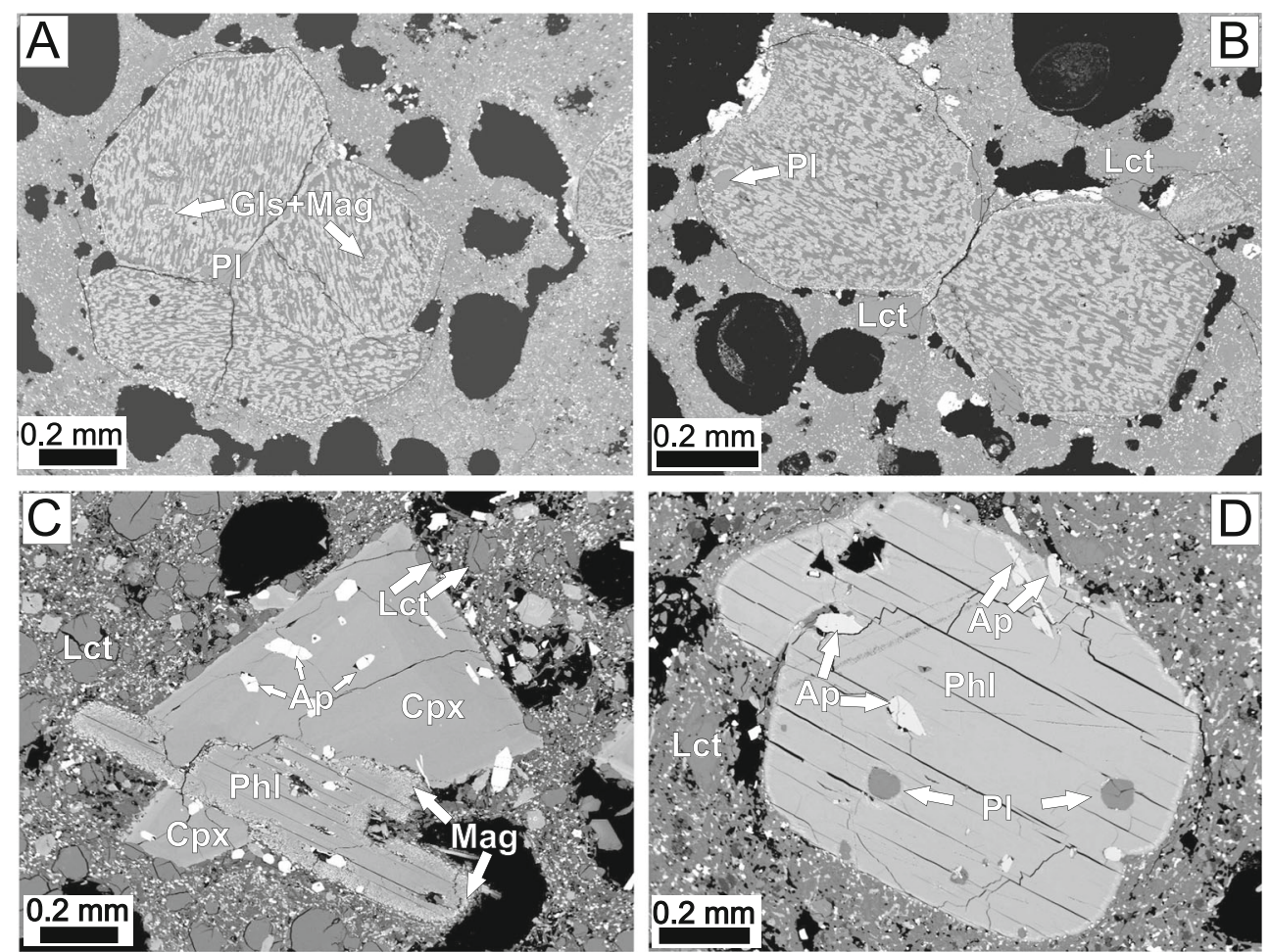

Fig. 3 BSE images of selected textural features. a Slightly rounded structure composed of four coalescing subhedral units in the matrix of sample Volbise. The form of the units suggests that they are/were crystalline. Each unit comprises an intergrowth of olivine $\mathrm{F}_{97}$ (darker) and a more $\mathrm{Fe}$-rich olivine $\left(\mathrm{Fo}_{76}\right.$ : lighter). The sub-rounded inclusions are glass (Gl), speckled with bright Fe-Ti-oxide (Mt). The structure is surrounded by a ring of vesicles. b Two units coalesce in similar style

to (a), with the same two olivine types. Note the concentration of coarser grains of Fe-Ti-oxides around much of the edge of the units and the rim of tiny granules of oxide. Lct, leucite. Sample Volbise. c Phlogopite (Phl) with opacitic rims intergrown with clinopyroxene phenocryst in sample VX. Apatite (Ap) microphenocrysts are common in the pyroxene. Leucite and clinopyroxene also occur as microphenocrysts. d Phlogopite phenocryst contains inclusions of plagioclase and apatite. Sample L2h 
Partially devitrified examples include feathery crystals of clinopyroxene, bright on BSE images.

\section{Mineral compositions}

\section{Olivine}

Representative compositions of olivine phenocrysts are given in Table 2; the full data set is in Supplementary Table 1. The range of compositions is from $\mathrm{Fo}_{46-88.5}$, although only three analyses, from crystal rims, have $F_{0}<65$. The highest Fo values are from the core of a crystal $1945 \mu \mathrm{m}$ in length in sample L1e (Fig. 2a) and are close to the values $\left(\mathrm{Fo}_{89.5-90.4}\right)$ considered by Marianelli et al. (1995) to represent the olivines from primary tephritic magmas of Vesuvius. Nickel contents are low $(\mathrm{NiO} \leq 0.24$ wt.\%) and positively correlated with Fo. In contrast, $\mathrm{CaO}$ contents are $\leq 0.45$ wt. $\%$ and generally increase with decreasing Fo content. The $\mathrm{CaO}$ values are relatively high; Pichavant et al. (2014), for example, reported

Table 2 Representative compositions of olivine phenocrysts

\begin{tabular}{|c|c|c|c|c|c|c|c|c|}
\hline & 1 & 2 & 3 & 4 & 5 & 6 & 7 & 8 \\
\hline \multicolumn{9}{|l|}{ wt. $\%$} \\
\hline $\mathrm{SiO}_{2}$ & 36.84 & 37.55 & 36.72 & 41.75 & 38.09 & 39.56 & 37.36 & 37.21 \\
\hline $\mathrm{TiO}_{2}$ & 0.03 & bd & 0.04 & bd & bd & bd & bd & bd \\
\hline $\mathrm{Cr}_{2} \mathrm{O}_{3}$ & bd & 0.03 & 0.05 & 0.04 & bd & bd & bd & bd \\
\hline $\mathrm{NiO}$ & bd & 0.05 & bd & 0.17 & 0.15 & 0.19 & bd & bd \\
\hline $\mathrm{FeO}^{*}$ & 30.01 & 25.05 & 31.24 & 10.51 & 23.62 & 17.62 & 26.59 & 27.27 \\
\hline $\mathrm{MnO}$ & 0.69 & 0.41 & 0.73 & 0.21 & 0.43 & 0.23 & 0.54 & 0.52 \\
\hline $\mathrm{MgO}$ & 31.46 & 35.64 & 30.82 & 45.33 & 37.72 & 41.86 & 34.85 & 34.14 \\
\hline $\mathrm{CaO}$ & 0.27 & 0.35 & 0.28 & 0.26 & 0.33 & 0.31 & 0.27 & 0.30 \\
\hline Total & 99.30 & 99.08 & 99.88 & 98.27 & 100.34 & 99.77 & 99.61 & 99.44 \\
\hline \multicolumn{9}{|c|}{ Formulae based on 4 oxygens } \\
\hline $\mathrm{Si}$ & 1.005 & 1.002 & 1.002 & 1.041 & 0.995 & 1.008 & 0.999 & 1.000 \\
\hline $\mathrm{Ti}$ & 0.001 & 0.000 & 0.001 & 0.000 & 0.000 & 0.000 & 0.000 & 0.000 \\
\hline $\mathrm{Cr}$ & 0.000 & 0.001 & 0.001 & 0.000 & 0.000 & 0.000 & 0.000 & 0.000 \\
\hline $\mathrm{Mg}$ & 1.279 & 1.417 & 1.254 & 1.684 & 1.470 & 1.590 & 1.388 & 1.367 \\
\hline $\mathrm{Ni}$ & 0.000 & 0.001 & 0.000 & 0.003 & 0.003 & 0.004 & 0.000 & 0.000 \\
\hline $\mathrm{Fe}^{2+}$ & 0.685 & 0.559 & 0.713 & 0.219 & 0.516 & 0.376 & 0.594 & 0.613 \\
\hline $\mathrm{Mn}$ & 0.016 & 0.009 & 0.017 & 0.004 & 0.010 & 0.005 & 0.012 & 0.012 \\
\hline $\mathrm{Ca}$ & 0.008 & 0.010 & 0.008 & 0.007 & 0.009 & 0.008 & 0.008 & 0.009 \\
\hline$\Sigma$ cations & 2.99 & 3.00 & 3.00 & 2.96 & 3.00 & 2.99 & 3.00 & 3.00 \\
\hline Fo\% & 65 & 72 & 64 & 88 & 74 & 81 & 69 & 69 \\
\hline
\end{tabular}

Explanation: 1, 2, core and rim of rounded crystal, sample L1; 3, 4, rim and core of olivine in Fig. 2b; 5, rim of rounded crystal, sample L3; 6, intermediate zone of inclusion in cpx, L1e; 7, 8, core and rim of large crystal, L2h. Textural details may be found in Supplementary Table 1

$\mathrm{FeO}^{*}$, all $\mathrm{Fe}$ as $\mathrm{Fe}^{2+}$. bd, below detection
$\mathrm{CaO}$ values up to $0.29 \mathrm{wt} . \%$ in experimental olivines from a Vesuvius tephrite and trachybasalt.

Detailed core to rim or rim to rim compositional profiles were made across several crystals (Supplementary Table 1). With one exception, the maximum range within crystals was $\mathrm{Fo}_{3}$. The exception was a slightly rounded crystal in sample $\mathrm{L} 1$ where the range is $\mathrm{Fo}_{76-65}$ but with no systematic variation from core to rim.

\section{Clinopyroxene}

Representative compositions of clinopyroxene phenocrysts are given in Table 3 and the full data set in Supplementary Table 2. Model $\mathrm{Fe}^{3+}$ and $\mathrm{Fe}^{2+}$ contents were calculated on the basis of 6 oxygens and 4 cations, using the method of Droop (1987). The range in compositions is $\mathrm{Ca}_{46.3} \mathrm{Mg}_{48.4} \mathrm{Fe}_{5.3}$ to $\mathrm{Ca}_{51.8} \mathrm{Mg}_{25.3} \mathrm{Fe}_{22.8}$, i.e., all are diopside in the classification scheme of Morimoto (1988) (Fig. 4). Levels of $\mathrm{Cr}$ are low $\left(0.37\right.$ wt. $\left.\% \mathrm{Cr}_{2} \mathrm{O}_{3}\right)$, except for two values of 0.51 and 0.91 wt. \% in the core of a zoned crystal in L1 (Supplementary Table 2). Vanadium levels are also low $\left(\leq 0.17\right.$ wt. $\left.\% \mathrm{~V}_{2} \mathrm{O}_{3}\right)$. In contrast, the pyroxenes are Al-rich, with up to 11.41 wt. $\% \mathrm{Al}_{2} \mathrm{O}_{3}$ (0.51 apfu). The $\mathrm{Al}$ contents increase with decreasing $\mathrm{Mg} \#$ (where $\mathrm{Mg \#}$ is magnesiumnumber, $\left.100 \mathrm{xMg} /\left(\mathrm{Mg}+\mathrm{Fe}^{2+}\right)\right)$. The ${ }^{\mathrm{vi}} \mathrm{Al} /{ }^{\text {iv }} \mathrm{Al}$ ratio is very variable, $0.01-1.0$, and does not vary systematically with any other geochemical parameter. Abundances of $\mathrm{TiO}_{2}$ range from 0.34 to 2.77 wt. $\%$ and are negatively correlated with $\mathrm{Mg \# .} \mathrm{Al} /$ Ti ratios, with one exceptional value of 13.0, are in the range $6.1-10.3$, average 7.6 , broadly similar to the range (6.9-13.5; average 10.1) in the clinopyroxenes from the experiments of Pichavant et al. (2014). Apart from $\mathrm{Mg} \leftrightarrow \mathrm{Fe}$, the dominant substitution mechanism involves the Tschermak's molecule (Fig. 5). Sodium levels are uniformly low $\left(\mathrm{Na}_{2} \mathrm{O}\right.$ $\leq 0.77$ wt.\%) and negatively correlated with $\mathrm{Mg \#}$. Oxidation ratios $\left(\mathrm{Fe}^{3+} /\left(\mathrm{Fe}^{3+}+\mathrm{Fe}^{2+}\right)\right)$ vary from 0.02 to 1 (Supplementary Table 2) and show a negative correlation with $\mathrm{Mg \#}$ and $\mathrm{Al}$, i.e., the most Fe-Al-rich pyroxenes are also the most oxidised, consistent with an increasing ferriTschermak's molecule (Fig. 6).

We noted above the complex compositional zoning in the pyroxenes. To provide information on magmatic evolutionary processes, detailed profiles were made across 24 crystals to determine the extent and nature of the zoning (Supplementary Table 2). Four representative examples are described here.

The phenocryst shown in Fig. 7a (L2h) has a magnesian core, dark on the BSE image, with Mg\# 86-90. The core has a thin mantle where the $\mathrm{Mg} \#$ drops sharply to 73 , which is then mantled by a brighter, fairly homogeneous zone of the same composition, except for a slight increase in $\mathrm{Mg \#}$ close to the rim. The partly resorbed core of the phenocryst in Fig. 7b contains a darker component ( $\mathrm{Mg} \#$ 85-81) partly replaced and mantled by a lighter component $(\mathrm{Mg} \# \sim 75)$, which is in 
Table 3 Representative compositions of clinopyroxene phenocrysts

\begin{tabular}{|c|c|c|c|c|c|c|c|c|}
\hline & 1 & 2 & 3 & 4 & 5 & 6 & 7 & 8 \\
\hline \multicolumn{9}{|l|}{ wt.\% } \\
\hline $\mathrm{SiO}_{2}$ & 53.80 & 49.06 & 52.43 & 50.15 & 52.26 & 44.43 & 52.43 & 50.15 \\
\hline $\mathrm{TiO}_{2}$ & 0.35 & 0.97 & 0.58 & 0.94 & 0.44 & 1.93 & 0.58 & 0.94 \\
\hline $\mathrm{Al}_{2} \mathrm{O}_{3}$ & 1.32 & 5.40 & 2.61 & 4.29 & 2.36 & 9.21 & 2.61 & 4.29 \\
\hline $\mathrm{Cr}_{2} \mathrm{O}_{3}$ & 0.10 & bd & 0.28 & 0.19 & 0.08 & 0.02 & 0.28 & 0.19 \\
\hline $\mathrm{V}_{2} \mathrm{O}_{3}$ & bd & bd & bd & bd & bd & 0.16 & bd & bd \\
\hline $\mathrm{FeO} *$ & 3.42 & 8.48 & 5.95 & 6.78 & 3.74 & 8.99 & 5.95 & 6.78 \\
\hline $\mathrm{MgO}$ & 17.40 & 13.19 & 16.24 & 14.65 & 16.59 & 11.14 & 16.24 & 14.65 \\
\hline $\mathrm{NiO}$ & bd & bd & bd & bd & 0.03 & 0.02 & bd & bd \\
\hline $\mathrm{MnO}$ & 0.09 & 0.20 & 0.16 & 0.13 & 0.13 & 0.13 & 0.16 & 0.13 \\
\hline $\mathrm{CaO}$ & 23.13 & 22.04 & 22.10 & 22.65 & 23.88 & 22.75 & 22.10 & 22.65 \\
\hline $\mathrm{Na}_{2} \mathrm{O}$ & 0.16 & 0.34 & 0.23 & 0.24 & 0.12 & 0.31 & 0.23 & 0.24 \\
\hline Total & 99.77 & 99.68 & 100.58 & 100.02 & 99.63 & 99.09 & 100.58 & 100.02 \\
\hline \multicolumn{9}{|c|}{ Formula on the basis of 6 oxygens and calculated $\mathrm{Fe}^{3+}$ and $\mathrm{Fe}^{2+}$} \\
\hline $\mathrm{Si}$ & 1.962 & 1.831 & 1.913 & 1.850 & 1.914 & 1.675 & 1.913 & 1.850 \\
\hline $\mathrm{Ti}$ & 0.010 & 0.027 & 0.016 & 0.026 & 0.102 & 0.055 & 0.016 & 0.026 \\
\hline $\mathrm{Al}$ & 0.057 & 0.238 & 0.112 & 0.187 & 0.102 & 0.409 & 0.112 & 0.187 \\
\hline $\mathrm{Cr}$ & 0.003 & 0.000 & 0.008 & 0.006 & 0.002 & 0.000 & 0.008 & 0.006 \\
\hline V & 0.000 & 0.000 & 0.000 & 0.000 & 0.000 & 0.005 & 0.000 & 0.000 \\
\hline $\mathrm{Fe}^{3+}$ & 0.008 & 0.070 & 0.037 & 0.072 & 0.052 & 0.151 & 0.037 & 0.072 \\
\hline $\mathrm{Fe}^{2+}$ & 0.097 & 0.194 & 0.144 & 0.137 & 0.062 & 0.133 & 0.144 & 0.137 \\
\hline $\mathrm{Mg}$ & 0.946 & 0.734 & 0.883 & 0.806 & 0.906 & 0.626 & 0.883 & 0.806 \\
\hline $\mathrm{Ni}$ & 0.000 & 0.000 & 0.000 & 0.000 & 0.001 & 0.001 & 0.000 & 0.000 \\
\hline $\mathrm{Mn}$ & 0.003 & 0.000 & 0.005 & 0.004 & 0.004 & 0.004 & 0.005 & 0.004 \\
\hline $\mathrm{Ca}$ & 0.904 & 0.881 & 0.864 & 0.895 & 0.937 & 0.919 & 0.864 & 0.895 \\
\hline $\mathrm{Na}$ & 0.011 & 0.025 & 0.016 & 0.017 & 0.008 & 0.022 & 0.016 & 0.017 \\
\hline$\Sigma$ cations & 4.00 & 4.00 & 4.00 & 4.00 & 4.00 & 4.00 & 4.00 & 4.00 \\
\hline Wo & 46.3 & 46.9 & 44.8 & 46.9 & 46.9 & 50.3 & 44.8 & 46.9 \\
\hline En & 48.4 & 39.0 & 45.8 & 42.2 & 46.3 & 34.2 & 45.8 & 42.2 \\
\hline Fs & 5.3 & 14.1 & 9.4 & 10.9 & 5.9 & 15.5 & 9.4 & 10.9 \\
\hline
\end{tabular}

Explanation: 1, 2, core area and rim of phenocryst in Fig. 6a, sample L2h; 3, 4, core and rim of rectangular plate, L2f; 5, 6, core and rim, strongly zoned crystal in Fig. 6d, VX; 7, 8, core and rim, platy crystal, L2f

$\mathrm{FeO}^{*}$, all $\mathrm{Fe}$ as $\mathrm{Fe}^{2+}$. bd, below detection turn mantled by a more magnesian, oscillatory zoned area with $\mathrm{Mg} \#$ varying from 76-80. The compositional variation along a core to rim profile in a phenocryst from L3 (Fig. 7c) shows a relatively homogeneous central zone (Mg\# 79-81) followed by an oscillatory zoned section (Mg\# 79-83), a zone showing a slight increase in $\mathrm{Mg}(\mathrm{Mg} \#$ 78-81), then a drop to $\mathrm{Mg} \# 77$ with another slight increase in $\mathrm{Mg}$ (to $\mathrm{Mg} \# 79$ ), a sharp drop to $\mathrm{Mg} \# 70$, a sharp rise to $\mathrm{Mg} \# 77$ and a final drop to $\mathrm{Mg} \# 74$. In Fig. 7 d, the phenocryst core comprises a more magnesian component $(\mathrm{Mg} \# \sim 88)$ patchily replaced by a brighter, more Fe-rich component (Mg\# 56-83), which is in turn sharply replaced by a more Fe-rich mantle showing oscillatory zoning (Mg\# 70-78) and finally an Fe-rich rim (Mg\# 69).

Similar variations in the style of zoning may be found within individual samples. The amount of zoning is, however, variable: In samples Vo2f, L1e, L1, L3 and V1, the Mg\# varies by $11-13$, in Volbisb by 5; and in the phlogopitephyric samples L2h and VX by $32-37$. However, a general theme is of more magnesian cores being partially replaced by a more Fe-rich phase, with a mantle which is either relatively homogeneous or oscillatory zoned. We interpret this to suggest that relatively Mg-rich, higher-temperature crystals were entrapped in less mafic magmas and partially resorbed and replaced, perhaps via entrapment of a crystal mush, as envisaged by Piochi et al. (2006). Before resorption was complete, further magma mixing resulted in precipitation of a more Fe-rich pyroxene. The sharp changes in $\mathrm{Mg} \#$ seen in all the profiles (Fig. 7) are thus ascribed to magma mixing, with inputs of either more or less Fe-rich magma than the host magma. That clinopyroxene phenocrysts hold a record of magma mixing at Vesuvius has previously been proposed by 
Fig. 4 Compositions of clinoproxene phenocrysts plotted in the Wo-En-Fs quadrilateral. Field boundaries from Morimoto (1988). The shaded areas are fields in which clinopyroxenes are not normally found (from Deer et al. 1997). Data from Supplementary Table 2

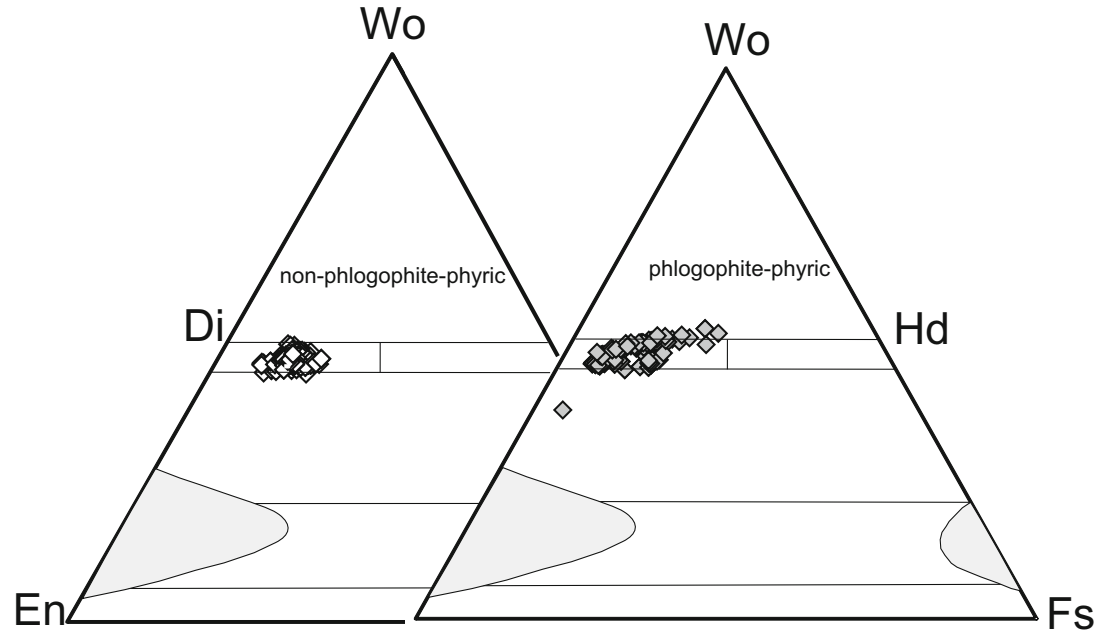

Cioni et al. (1998), Landi et al. (1999), Marianelli et al. (1999) and Fulignati et al. (2004).

\section{Phlogopite}

Phlogopite phenocrysts in VX and L2h have Mg\# (calculated with total $\mathrm{Fe}$ as $\mathrm{Fe}^{2+}$ ) in the ranges 73-77 and 68-70, respectively, much lower than in primary phlogopite from mantle lherzolites (Mg\# 90; Delaney et al. 1980) but comparable to those determined in experimental phlogopites in Vesuvius rocks by Pichavant et al. (2014) (Mg\# 70-80). Alumina values range from 15.11 to $16.56 \mathrm{wt} . \%$ and $\mathrm{Na}_{2} \mathrm{O}$ levels from 0.38 to 0.92 wt. \%; both are positively correlated with $\mathrm{Mg \#}$. Atomic $\mathrm{K} /(\mathrm{K}+\mathrm{Na})$ is between 0.87 and 0.94 . Titanium contents are

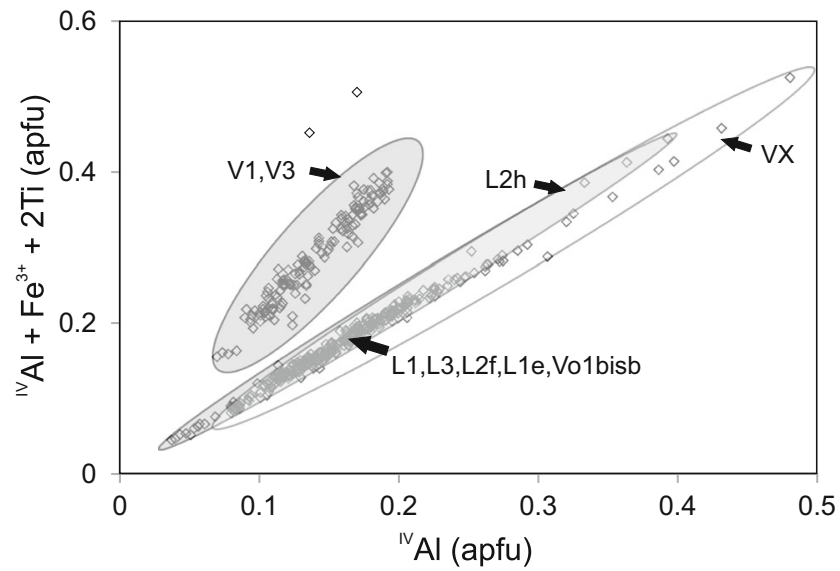

Fig. 5 Plot to show the incorporation of the Tschermak component $\left(\mathrm{CaAlAlSiO}_{6}\right)$ into the clinopyroxene phenocrysts. Note how the pyroxenes in the phlogopite-phyric samples (VX and L2H) cover essentially the entire compositional range, reflecting the presence in them of highly magnesian cores. Data from Supplementary Table 2 high $\left(\mathrm{TiO}_{2} 3.66-6.68\right.$ wt.\%) and are negatively correlated with Mg\# (Table 4; Supplementary Table 4c). The $\mathrm{TiO}_{2}$ levels are generally similar to those over the same $\mathrm{Mg} \#$ range in the experiments of Pichavant et al. (2014) and in the natural Vesuvius rocks (Fig. 8). Abundances of $\mathrm{BaO}$ vary from 0.63 to 2.08 wt.\%, increasing with decreasing $\mathrm{Mg \# .} \mathrm{Cl}$ contents are low, $0.05-0.13$ wt.\%, whereas $\mathrm{F}$ contents range from 0.39 to 3.28 wt.\% and do not show any correlation with Mg\#. Of particular importance in assessing the role of phlogopite in determining the compositions of residual melts is its strongly silica-undersaturated nature, with CIPW-normative (ne+lct+ ks) contents in the range $41-44 \%$.

Zoning in the phlogopite is weak. A rim-to-rim profile across the phlogopite shown in Fig. 3d, for example, revealed little compositional variation, $\mathrm{Mg} \#$ varying from 68 to 70 (Supplementary Table 2c, nos. 12-18). A second crystal has a slightly wider range (63-69; nos. 19-25). There is no systematic core to rim variation.

\section{Leucite}

Analyses of leucite phenocrysts are provided in Supplementary Table 3a. They are almost pure $\mathrm{K}$ end-member, with $\mathrm{Na} \leq 0.03$ apfu and $\mathrm{Ba}<0.01$ apfu. Calcium and $\mathrm{Fe}^{3+}$ levels are also low, $\leq 0.11$ and $<0.02 \mathrm{apfu}$, respectively. Zoning, where present, is minor; for example, a crystal in sample Vo12f is zoned from $\mathrm{K} /(\mathrm{K}+\mathrm{Na}) 0.94-0.98$, with a slight increase in the ratio towards the rim. A profile parallel to the edge of a crystal in a leucite in Volbisb gave the range 0.94-1.00.

\section{Plagioclase}

Plagioclase phenocryst compositions range from $\mathrm{An}_{92} \mathrm{Ab}_{7} \mathrm{Or}_{1}$ to $\mathrm{An}_{43} \mathrm{Ab}_{41} \mathrm{Or}_{16}$, and follow an overall trend of K-enrichment (Fig. 9; Supplementary Table 3b). The most calcic phase (An 

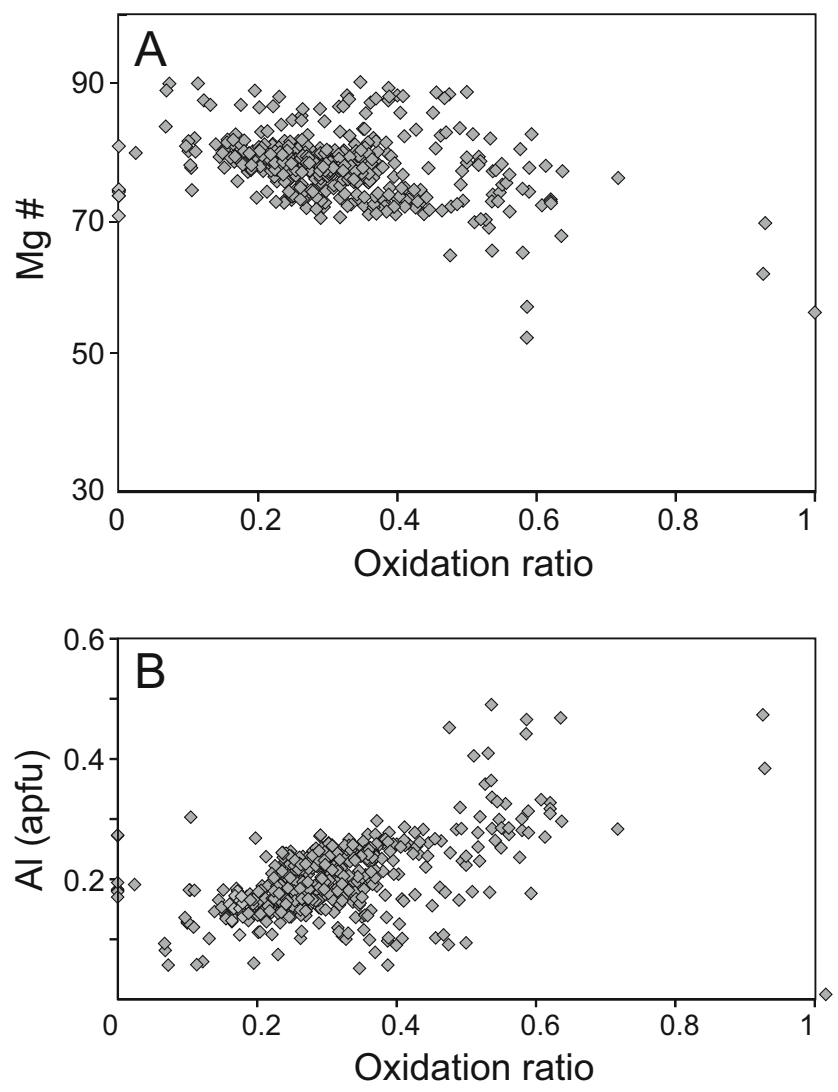

Fig. 6 Oxidation ratio $\left(\mathrm{Fe}^{3+} /\left(\mathrm{Fe}^{3+}+\mathrm{Fe}^{2+}\right)\right)$ plotted against (a) $\mathrm{Mg}$ and (b) total Al (apfu) for clinopyroxene phenocrysts. The most Al-rich, Mg-poor clinopyroxenes tend to be the most oxidised. Data from Supplementary Table 2

$\leq 92.7$ ) occurs in the core of a euhedral octagonal plate in sample L2h, with marked normal zoning to a more sodic rim $\left(\mathrm{An}_{55} \mathrm{Ab}_{41} \mathrm{Or}_{4}\right)$. In other phenocrysts the zonation is more random and reverse, normal and oscillatory zoning occur (Fig. 2c, d). Where well developed, zoning goes through ternary feldspar to almost pure K-feldspar (Fig. 9).

\section{Fe-Ti-oxides}

The data set for Fe-Ti-oxides is limited due to the uncertainty as to what constitutes true microphenocrysts; the textural features of analysed phases are given in Supplementary Table 4a.

Two inclusions in a clinopyroxene phenocryst in sample L1 are titanomagnetite, with $X_{\text {usp }} 51.4$ and 31.8, respectively. Various forms of titanomagnetite in sample VX have much lower $X_{\text {usp }}$ (2.6-8.7), whereas $X_{\text {usp }}$ in L2h is 18.5-26.8. Ilmenite has been found only as lamellae in a titanomagnetite crystal in L2h ( $X_{\text {ilm }}$ 92).

The absence of $\mathrm{Cr}$ spinel is probably due to the low $\mathrm{Cr}$ concentrations in the whole-rocks $(\leq 160 \mathrm{ppm})$. Pichavant et al. (2014) also attributed the lack of spinel in their experiments on Vesuvius rocks to low $\mathrm{Cr}$ abundances in their starting materials.

\section{Apatite}

Representative apatite analyses are presented in Table 5 and the full data set in Supplementary Table 4b. Formulae have been calculated on the basis of 13 oxygens; $\mathrm{OH}$ values are $1-(\mathrm{F}+\mathrm{Cl})$. Fluorine exceeds $\mathrm{OH}$ in the anion site and the mineral is fluorapatite. The sums of cations range from 7.96 to 8.20 (average 8.11) apfu. Levels of $\mathrm{FeO}^{*}$ and $\mathrm{SrO}$ are low $(\leq 1.26$ wt. $\%$ and $\leq 0.31$ wt. $\%$, respectively). With one exceptional analysis with 1.15 wt. $\%, \mathrm{SO}_{3}$ levels are $\leq 0.66$ wt.\%. Chlorine abundances range up to 1.14 wt.\% (0.168 apfu). The main substitution mechanism is $\mathrm{Ca}^{2+}+\mathrm{P}^{5+} \leftrightarrow \mathrm{REE}^{3+}+\mathrm{Si}^{4+}$ and the maximum britholite component is $\sim 3 \%$ (Fig. 10). The highest values occur in both cores and rims, i.e., both normal and reversed zoning are present.

\section{Whole-rock and matrix glass compositions}

Major and trace element data are given in Table 6. In the TAS classification scheme (Le Bas et al. 1986), the whole-rocks span the phonotephrite/basaltic trachyandesite boundary. All rocks are nepheline-normative (ne 3-13\%); VX is also leucite-normative (lct $7.4 \%$ ). Whole-rock Mg\# range from 62 to 49 . These are relatively low values for mafic Vesuvius rocks; Villemant et al. (1993), for example, reported rocks from the 1944 eruption with Mg\# up to 71 and Marianelli et al. (1995) recorded tephritic melt inclusions in products of the 1906 eruption with $\mathrm{Mg} \#$ of 72-75 which they considered to represent Vesuvius primary magmas. Lima et al. (1999) found melt inclusions in clinoproxenes of the mediaeval Terzigno Formation with Mg\# 75-91, which they considered to represent primitive magma compositions. Pichavant et al. (2014) identified the following features of Vesuvius primitive magmas: they are trachybasaltic, with $\mathrm{K}_{2} \mathrm{O} \sim 4.5-5.5$ wt.\%, $\mathrm{K}_{2} \mathrm{O} / \mathrm{Na}_{2} \mathrm{O}$ between 2.75 and $4, \mathrm{MgO}=8-9$ wt.\%, $\mathrm{Mg \#}$ between 75 and 80 and $\mathrm{CaO} / \mathrm{Al}_{2} \mathrm{O}_{3}$ between 0.9 and 0.95 . Along with low $\mathrm{Ni}$ abundances $(\leq 37 \mathrm{ppm})$, it is clear that the magmas feeding the eccentric and parasitic cones experienced significant intracrustal fractionation.

With decreasing $\mathrm{MgO}$ content, whole-rocks show increases in $\mathrm{TiO}_{2}, \mathrm{Al}_{2} \mathrm{O}_{3}, \mathrm{Fe}_{2} \mathrm{O}_{3} *$ (all $\mathrm{Fe}$ as $\mathrm{Fe}^{3+}$ ), $\mathrm{MnO}$ and $\mathrm{Na}_{2} \mathrm{O}$, and decreases in $\mathrm{CaO}$. Levels of $\mathrm{SiO}_{2}, \mathrm{~K}_{2} \mathrm{O}$ and $\mathrm{P}_{2} \mathrm{O}_{5}$ are about constant (Fig. 11). The data for the cones are too scattered to represent a single liquid line of descent, indicating derivation from more than one parental magma and/or data scattering through phenocryst accumulation or depletion (Belkin et al. 1993; Villemant et al. 1993; Piochi et al. 2006).

Trace element data show the high abundances of strongly incompatible trace elements characteristic of Vesuvius rocks: 
Fig. 7 BSE images of clinopyroxene phenocrysts selected to show the variation in style of compositional zoning. Compositional variations along the marked profiles are shown below each image. See the text for details. a Sample L2h. b Sample Vo2f. c Leucite crystals form a discontinuous ring close to the edge of a phenocryst in sample L3. Small olivine crystals are included in the clinopyroxene, in one case rimmed by glass. $\mathbf{d}$ Phenocryst in sample LX. The darker core region shows a complex history of crystallization and resorption, perhaps related to magma mixing, and is mantled by an oscillatory zoned area. Data for profiles from Supplementary Table 2, numbers 28-67, 68-104, 213-261, and 290-346, respectively
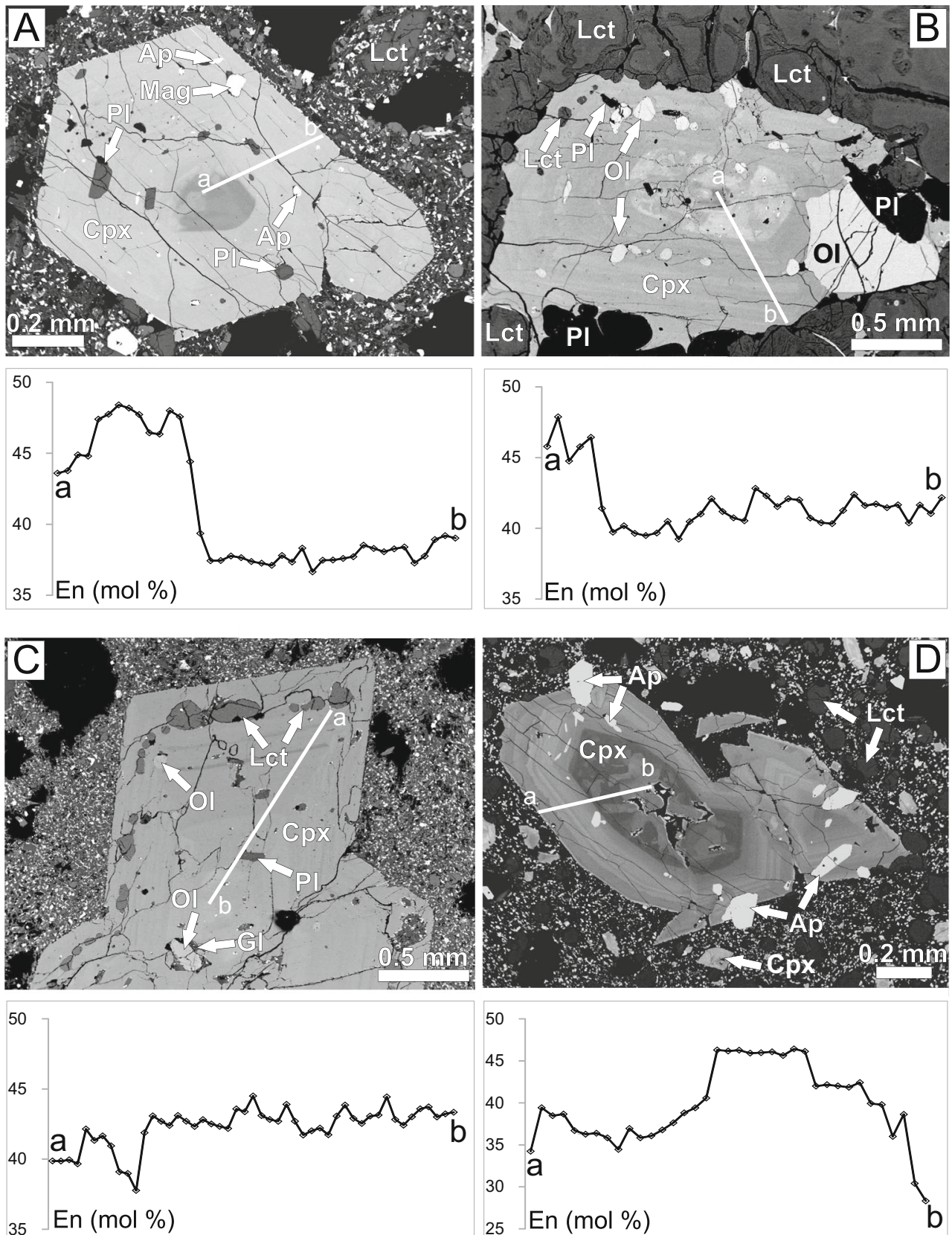

Ba 1303-2336 ppm, Cs 10.5-20 ppm, Rb 210-314 ppm, Sr 717-1129 ppm, Th 11.9-20.8 ppm and U 3.8-8.7 ppm. The chondrite-normalised REE patterns for all rocks are very similar (Fig. 12), showing essentially constant $[\mathrm{La} / \mathrm{Sm}]_{\mathrm{CN}}$ ratios (31-36), a small range of LREE-enrichment relative to HREE $\left([\mathrm{La} / \mathrm{Yb}]_{\mathrm{cn}} 14.2-17.2\right)$ and modest negative Eu anomalies $(\mathrm{Eu} /$ $\mathrm{Eu}^{*}$ 0.79-0.91). The abundances of the compatible trace elements are very similar to those recorded by Ayuso et al. (1998) for the same range of $\mathrm{MgO}$ contents: Co 23-33 ppm, Cr 14178 ppm, Ni 7-37 ppm, Sc 6-32 ppm and V 189-232 ppm. With decreasing $\mathrm{MgO}$ content, there are decreases in $\mathrm{Co}, \mathrm{Cr}$, $\mathrm{Ni}, \mathrm{Sc}$ and $\mathrm{V}$ contents and overall increases in $\mathrm{Ba}, \mathrm{Cs}, \mathrm{Ga}, \mathrm{Rb}$, REE, Y, Sr, Zr, Th, U, Nb and Ta contents.
The question arises: do the rocks containing phlogopite phenocrysts represent different magmatic lineages to those lacking phlogopite phenocrysts? Relatively narrow ranges among trace element ratios indicate close genetic linkages between the rocks (Ayuso et al. 1998); e.g., Th/U 2.4-3.3; $\mathrm{Ce} / \mathrm{Yb} 40-47, \mathrm{Zr} / \mathrm{Nb}$ 6.0-7.5. For the majority of major and trace elements the position of the phlogopite-phyric samples on the $\mathrm{MgO}$ plots is perfectly consistent with their being slightly more evolved members of the same suite as those lacking phlogopite phenocrysts (Fig. 11). There are, however, some subtle differences, in particular the slightly higher $\mathrm{CaO}$ and $\mathrm{Na}_{2} \mathrm{O}$ values at the same $\mathrm{MgO}$ level and the low $\mathrm{SiO}_{2}$ content in sample VX. These differences will be related below 
Table 4 Representative compositions of phlogopite phencrysts

\begin{tabular}{|c|c|c|c|c|c|c|c|c|}
\hline \multirow[t]{2}{*}{ Sample } & \multicolumn{4}{|c|}{$\mathrm{L} 2 \mathrm{~h}$} & \multicolumn{4}{|c|}{ VX } \\
\hline & 1 & 2 & 3 & 4 & 5 & 6 & 7 & 8 \\
\hline
\end{tabular}

\section{wt.\%}

$\begin{array}{lllllllll}\mathrm{SiO}_{2} & 35.90 & 36.43 & 35.88 & 35.10 & 36.50 & 35.54 & 35.72 & 36.81\end{array}$

$\begin{array}{lllllllll}\mathrm{TiO}_{2} & 6.65 & 5.85 & 5.95 & 5.42 & 3.97 & 4.83 & 4.85 & 3.89\end{array}$

$\begin{array}{lllllllll}\mathrm{Al}_{2} \mathrm{O}_{3} & 16.06 & 16.30 & 15.34 & 15.11 & 16.04 & 15.79 & 16.04 & 15.93\end{array}$

$\mathrm{Cr}_{2} \mathrm{O}_{3}$ bd bd bd bd bd 0.06 bd 0.07

$\begin{array}{lllllllll}\mathrm{FeO}^{*} & 11.73 & 12.56 & 12.04 & 15.21 & 10.27 & 11.05 & 10.95 & 10.12\end{array}$

$\begin{array}{lllllllll}\mathrm{MgO} & 15.40 & 14.79 & 15.27 & 14.39 & 17.85 & 16.57 & 16.47 & 17.99\end{array}$

$\begin{array}{lllllllll}\mathrm{MnO} & 0.09 & 0.08 & 0.07 & 0.13 & 0.12 & 0.01 & 0.11 & 0.04\end{array}$

$\mathrm{CaO}$ bd bd bd $0.08 \quad 0.03$ bd 0.05 bd

$\begin{array}{lllllllll}\mathrm{BaO} & 1.30 & 1.28 & 1.86 & 0.91 & 0.90 & 0.67 & 1.13 & 0.84\end{array}$

$\begin{array}{lllllllll}\mathrm{Na}_{2} \mathrm{O} & 0.42 & 0.59 & 0.48 & 0.55 & 0.80 & 0.78 & 0.50 & 0.84\end{array}$

$\begin{array}{lllllllll}\mathrm{K}_{2} \mathrm{O} & 9.29 & 9.01 & 9.24 & 8.98 & 8.85 & 8.71 & 9.04 & 9.43\end{array}$

$\begin{array}{lllll}\mathrm{F} & 0.77 & 2.17 & 0.75 & 1.99\end{array}$

$\mathrm{Cl} \quad 0.10 \quad 0.05 \quad 0.06 \quad 0.11$

$\begin{array}{lllllllll}\text { Sum } & 97.71 & 99.11 & 96.94 & 97.98 & 95.33 & 94.01 & 94.86 & 95.96\end{array}$

$\mathrm{O}=\mathrm{F}, \mathrm{Cl} \quad 0.35 \quad 0.92 \quad 0.33 \quad 0.86$

$\begin{array}{lllllllll}\text { Total } & 97.36 & 98.19 & 96.61 & 97.12 & 95.33 & 94.01 & 94.86 & 95.96\end{array}$

Formulae on the basis of 11 oxygen equivalents

\begin{tabular}{lllllllll}
$\mathrm{Si}$ & 2.612 & 2.613 & 2.648 & 2.586 & 2.687 & 2.662 & 2.661 & 2.696 \\
$\mathrm{Ti}$ & 0.364 & 0.316 & 0.330 & 0.300 & 0.220 & 0.272 & 0.272 & 0.214 \\
$\mathrm{Al}$ & 1.377 & 1.378 & 1.334 & 1.312 & 1.392 & 1.394 & 1.409 & 1.375 \\
$\mathrm{Cr}$ & 0.000 & 0.000 & 0.000 & 0.000 & 0.000 & 0.004 & 0.000 & 0.004 \\
$\mathrm{Fe}^{2+}$ & 0.714 & 0.753 & 0.743 & 0.937 & 0.632 & 0.692 & 0.682 & 0.620 \\
$\mathrm{Mg}$ & 1.670 & 1.581 & 1.680 & 1.580 & 1.958 & 1.850 & 1.829 & 1.964 \\
$\mathrm{Mn}$ & 0.006 & 0.005 & 0.004 & 0.008 & 0.007 & 0.001 & 0.007 & 0.002 \\
$\mathrm{Ca}$ & 0.000 & 0.000 & 0.000 & 0.006 & 0.002 & 0.000 & 0.004 & 0.000 \\
$\mathrm{Ba}$ & 0.037 & 0.036 & 0.054 & 0.026 & 0.026 & 0.020 & 0.033 & 0.024 \\
$\mathrm{Na}$ & 0.059 & 0.082 & 0.069 & 0.079 & 0.114 & 0.113 & 0.072 & 0.119 \\
$\mathrm{~K}$ & 0.862 & 0.824 & 0.870 & 0.844 & 0.831 & 0.832 & 0.859 & 0.881 \\
$\mathrm{~F}$ & 0.177 & 0.492 & 0.175 & 0.464 & & & & \\
$\mathrm{Cl}$ & 0.012 & 0.006 & 0.008 & 0.014 & & & & \\
$\Sigma$ cations & 7.70 & 7.59 & 7.92 & 8.16 & 7.87 & 7.84 & 7.83 & 7.90 \\
$\mathrm{Mg \#}$ & 0.70 & 0.68 & 0.69 & 0.63 & 0.76 & 0.73 & 0.73 & 0.76 \\
\hline
\end{tabular}

$\mathrm{FeO}^{*}$, all $\mathrm{Fe}$ as $\mathrm{Fe}^{2+}$. bd, below detection. Blank, not determined

to possible variations in the water content of the magmas. The phlogopite-phyric samples, VX and L2h, have different phenocryst assemblages (Table 1). They are also different compositionally, in, for example, $\mathrm{Na}_{2} \mathrm{O} / \mathrm{K}_{2} \mathrm{O}$ ratios $(0.44$ and 0.54 , respectively). They represent similar but different magmatic lineages.

Joron et al. (1987) and Ayuso et al. (1998) distinguished three groups of rocks at Somma-Vesuvius, characterised by different ages, degree of silica-undersaturation and enrichment in $\mathrm{K}_{2} \mathrm{O}$. According to Ayuso et al. (1998), the rocks of the first group consists of slightly silica-undersaturated potassic trachybasalt to trachyte, the second group consists of

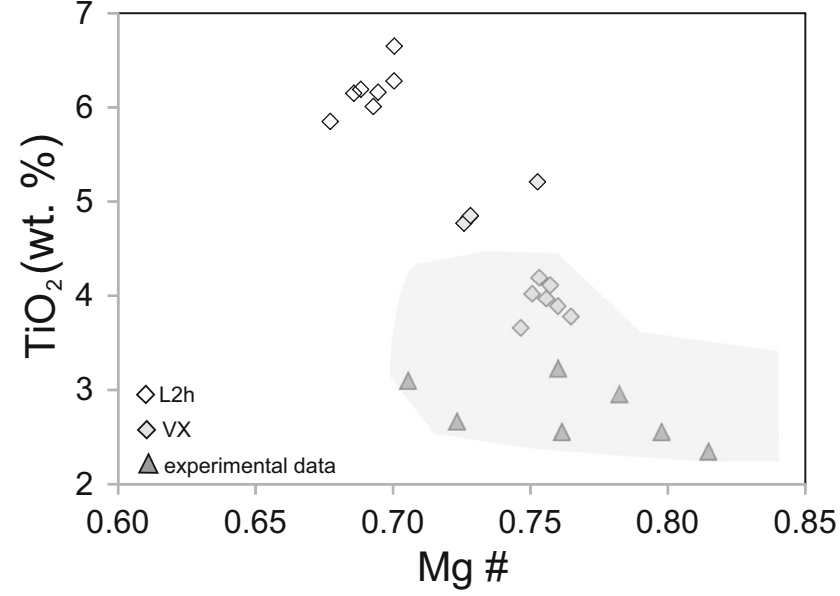

Fig. $8 \mathrm{Mg} \#-\mathrm{TiO}_{2}$ variation in phlogopite phenocrysts. The shaded field encloses data from Vesuvius lavas (from Pichavant et al. 2014). Also shown are the compositions of phlogopites from the experiments on Vesuvius samples by Pichavant et al. (2014). Data from Supplementary Table 4c

intermediate silica-undersaturated rocks, and the third group shows strongly undersaturated leucite-bearing rocks. The same, or very similar, trends have been recognised in other studies (Santacroce et al. 1993, 2008; Marianelli et al. 1995; Pichavant et al. 2014). The rocks of the eccentric and parasitic cones belong to the first group of Ayuso et al. (1998).

The range of matrix glass compositions in individual specimens is variable. In samples V1 and V3, for example, the glasses range from basaltic trachyandesitic to phonotephritic, in sample VX the glasses are all phonolitic, whilst in sample Vobis $1 \mathrm{~b}$ the range is from basaltic trachyandesite to tephriphonolite (Table 7; Supplementary Table 5a). In all

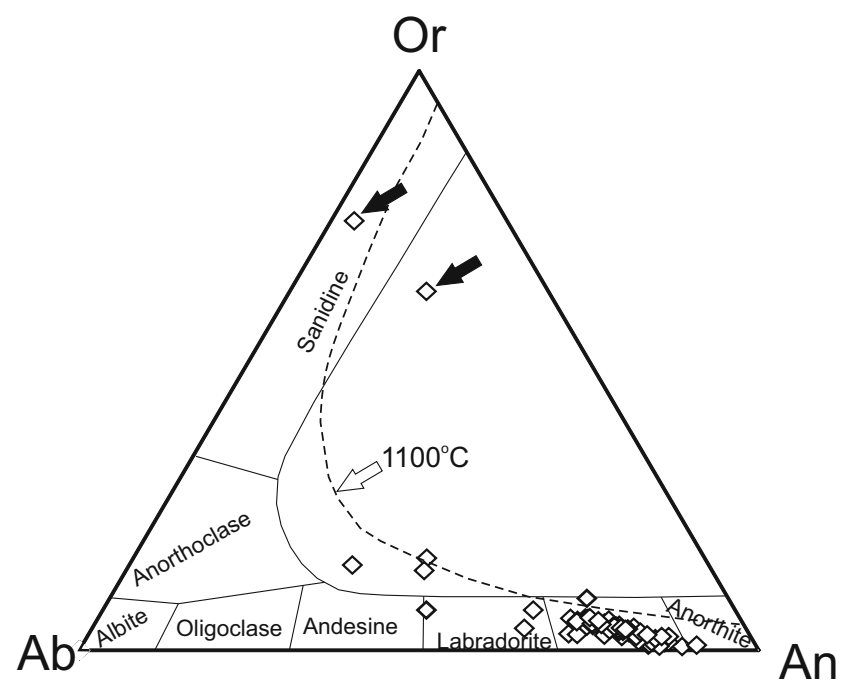

Fig. 9 Composition of plagioclase phenocrysts. Also shown (arrowed) are two analyses of K-rich feldspars forming rims to strongly zoned plagioclase phenocrysts. Solvus curve for $1100{ }^{\circ} \mathrm{C}$ from Elkins and Grove (1990). Data from Supplementary Table 3b 
Table 5 Representative compositions of apatite (micro)phenocrysts

\begin{tabular}{|c|c|c|c|c|c|c|c|c|}
\hline & 1 & 2 & 3 & 4 & 5 & 6 & 7 & 8 \\
\hline \multicolumn{9}{|l|}{ wt.\% } \\
\hline $\mathrm{P}_{2} \mathrm{O}_{5}$ & 40.75 & 41.11 & 41.43 & 41.33 & 40.27 & 40.83 & 41.03 & 40.70 \\
\hline $\mathrm{SiO}_{2}$ & 0.33 & 0.32 & 0.48 & 0.38 & 2.58 & 0.46 & 0.33 & 1.59 \\
\hline $\mathrm{Y}_{2} \mathrm{O}_{3}$ & 0.08 & bd & 0.06 & bd & bd & bd & 0.04 & bd \\
\hline $\mathrm{La}_{2} \mathrm{O}_{3}$ & bd & 0.21 & bd & bd & bd & 0.08 & bd & 0.12 \\
\hline $\mathrm{Ce}_{2} \mathrm{O}_{3}$ & bd & 0.20 & 0.21 & 0.20 & bd & 0.27 & 0.19 & 0.18 \\
\hline $\mathrm{MgO}$ & bd & 0.35 & 0.36 & 0.31 & 0.42 & 0.33 & 0.33 & 0.80 \\
\hline $\mathrm{CaO}$ & 55.32 & 55.35 & 54.88 & 54.79 & 52.51 & 55.19 & 55.10 & 53.26 \\
\hline $\mathrm{MnO}$ & bd & 0.08 & bd & 0.14 & bd & bd & bd & 0.10 \\
\hline $\mathrm{FeO}^{*}$ & 0.27 & 0.38 & 0.39 & 0.65 & 1.19 & 0.45 & 0.52 & 0.52 \\
\hline $\mathrm{SrO}$ & 0.18 & 0.15 & 0.13 & 0.15 & 0.09 & 0.14 & 0.15 & 0.04 \\
\hline $\mathrm{Na}_{2} \mathrm{O}$ & bd & 0.07 & 0.11 & 0.08 & bd & 0.05 & 0.07 & 0.09 \\
\hline $\mathrm{F}$ & 2.54 & 1.70 & 2.19 & 1.85 & 2.52 & 1.90 & 2.28 & 2.34 \\
\hline $\mathrm{Cl}$ & 0.55 & 0.59 & 0.56 & 0.62 & 0.40 & 0.51 & 0.50 & 0.65 \\
\hline $\mathrm{SO} 3$ & 0.13 & 0.34 & 0.44 & 0.13 & 0.16 & 0.22 & 0.09 & bd \\
\hline Sum & 100.15 & 100.85 & 101.24 & 100.63 & 100.14 & 100.43 & 100.63 & 100.39 \\
\hline $\mathrm{O}=\mathrm{F}, \mathrm{Cl}$ & 1.20 & 0.33 & 0.34 & 0.29 & 0.21 & 0.27 & 0.23 & 0.27 \\
\hline Total & 98.95 & 100.52 & 100.90 & 100.34 & 99.93 & 100.16 & 100.40 & 100.12 \\
\hline \multicolumn{9}{|c|}{ Formulae on the basis of 13 oxygens } \\
\hline Y & 0.004 & 0.000 & 0.003 & 0.000 & 0.000 & 0.000 & 0.002 & 0.000 \\
\hline $\mathrm{La}$ & 0.000 & 0.007 & 0.000 & 0.000 & 0.000 & 0.003 & 0.000 & 0.004 \\
\hline $\mathrm{Ce}$ & 0.000 & 0.006 & 0.007 & 0.006 & 0.000 & 0.008 & 0.006 & 0.006 \\
\hline $\mathrm{Ca}$ & 5.092 & 5.066 & 4.978 & 5.016 & 4.777 & 5.072 & 5.048 & 4.854 \\
\hline $\mathrm{Sr}$ & 0.009 & 0.007 & 0.006 & 0.007 & 0.004 & 0.007 & 0.007 & 0.002 \\
\hline $\mathrm{Na}$ & 0.000 & 0.012 & 0.018 & 0.013 & 0.000 & 0.008 & 0.012 & 0.015 \\
\hline $\mathrm{Mg}$ & 0.000 & 0.045 & 0.045 & 0.039 & 0.053 & 0.042 & 0.042 & 0.101 \\
\hline $\mathrm{Fe}$ & 0.019 & 0.027 & 0.028 & 0.046 & 0.085 & 0.032 & 0.037 & 0.037 \\
\hline $\mathrm{Mn}$ & 0.000 & 0.006 & 0.000 & 0.010 & 0.000 & 0.000 & 0.000 & 0.007 \\
\hline Sum M & 5.124 & 5.176 & 5.085 & 5.144 & 4.926 & 5.173 & 5.158 & 5.039 \\
\hline $\mathrm{P}$ & 2.963 & 2.972 & 2.968 & 2.988 & 2.894 & 2.964 & 2.969 & 2.930 \\
\hline $\mathrm{Si}$ & 0.028 & 0.027 & 0.041 & 0.032 & 0.219 & 0.039 & 0.028 & 0.135 \\
\hline S & 0.008 & 0.022 & 0.028 & 0.008 & 0.010 & 0.014 & 0.006 & 0.000 \\
\hline Sum T & 2.999 & 3.021 & 3.037 & 3.029 & 3.123 & 3.017 & 3.003 & 3.065 \\
\hline $\mathrm{F}$ & 0.690 & 0.459 & 0.586 & 0.500 & 0.677 & 0.515 & 0.617 & 0.630 \\
\hline $\mathrm{Cl}$ & 0.081 & 0.087 & 0.081 & 0.091 & 0.058 & 0.075 & 0.073 & 0.095 \\
\hline $\mathrm{OH}$ & 0.229 & 0.454 & 0.332 & 0.409 & 0.265 & 0.410 & 0.310 & 0.276 \\
\hline$\Sigma$ cations & 8.12 & 8.20 & 8.12 & 8.17 & 8.05 & 8.19 & 8.16 & 8.10 \\
\hline
\end{tabular}

Explanation: 1, inclusion in cpx, sample VX; 2, 3, core and rim, inclusion in cpx, L2h; 4, 5, core and rim, inclusion in phlogopite, L2h; 6, 7, core and rim in olivine, L2h; 8, core of euhedral prism, L1e

$\mathrm{FeO}^{*}$, all $\mathrm{Fe}$ as $\mathrm{Fe}^{2+}$. bd, below detection cases, however, the glasses are less silica-undersaturated than the host rock. Compositional data for melt inclusions (MI) are available for three rocks (Table 7; Supplementary Table 5a). In sample Vo2f, they are compositionally similar to the host rock, suggesting relatively early entrapment in the phenocrysts. In contrast, the MI in Volbisb range from phonotephrite to tephriphonolite, indicating either entrapment over a significant part of the crystallization history or magma mixing.
Chlorine abundances in the matrix glasses of Type 1 rocks range from 0.03 to $0.08 \mathrm{wt} . \%$ in sample $\mathrm{L} 1$ to $0.23-0.55 \mathrm{wt} . \%$ in sample Volbis $1 \mathrm{~b}$ (Supplementary Table 5a). The higher values are broadly similar to those $(\leq 0.58 \mathrm{wt} . \%)$ recorded in Vesuvius mafic rocks by Marianelli et al. (1995, 1999), Raia et al. (2000) and Lima et al. (2003). The matrix glass in sample VX is more Cl-rich (0.42-1.03 wt.\%). We have limited data for $\mathrm{Cl}$ in melt inclusions (Supplementary Table 5a), maximum 


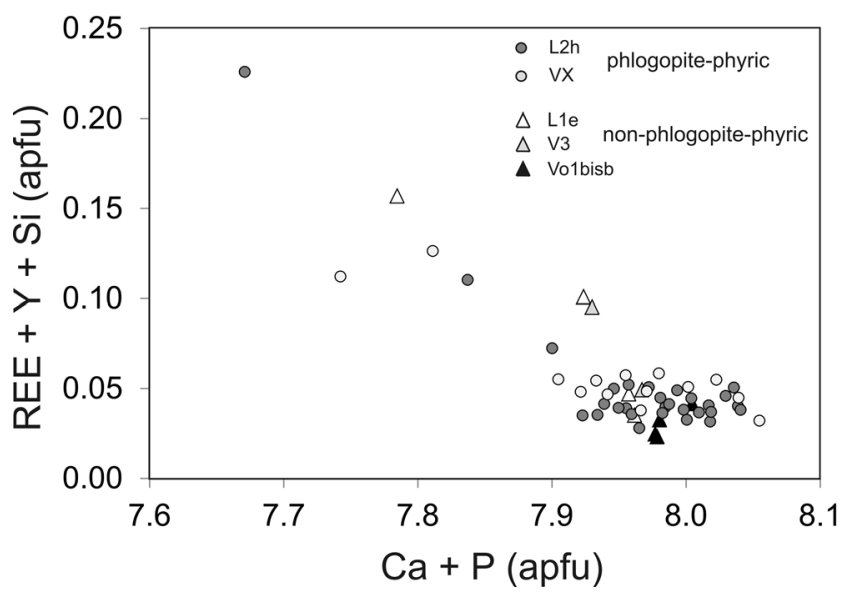

Fig. 10 Main substitution mechanism in apatite microphenocrysts. The most $(\mathrm{REE}+\mathrm{Y}+\mathrm{Si}$ )-rich composition corresponds to $\sim 3 \%$ of the britholite component. Analyses from the phlogopite-phyric samples (VX and L2h) cover the whole compositional range. Data from Supplementary Table $4 b$

abundances being $0.46 \mathrm{wt} . \%$ in L1e (Type 1) and $1.00 \mathrm{wt.} \%$ in VX, suggesting that the phlogopite-phyric magmas were richer in $\mathrm{Cl}$ than Type 1 magmas. Fluorine concentrations are below detection $(\sim 0.16 \mathrm{wt} . \%)$ in the majority of glass analyses. The matrix glass in sample Vobis $1 \mathrm{~b}$ contains 0.29 , 0.57 wt. \% F and a melt inclusion in sample Vo2f has $0.21-$ 0.24 wt.\% F. A melt inclusion in sample VX has $\mathrm{F}$ varying from below detection to $0.74 \mathrm{wt} . \%$, perhaps indicating strong variability in the host magma.

\section{Discussion}

\section{Petrogenesis}

\section{Geochemical evidence}

The low Mg\# and Ni contents preclude any of the rocks from the cones being a primary magma. It is probable that they were derived from tephritic magmas by fractionation of olivine and clinopyroxene, as proposed for rocks of similar composition by Marianelli et al. (1995, 1999, 2005), Fulignati et al. (2004) and Pichavant et al. (2014). The high Mg\# cores of some clinopyroxene phenocrysts are residual from that earlier stage of evolution. On the major element $v$. MgO plots, tephritic melt inclusions are plausible parental magmas to the phonoteprites (Fig. 11).

The compositional evolution of the parental tephrites at Vesuvius is well established (Santacroce et al. 1993, 2008; Marianelli et al. 1995, 1999, 2005; Fulignati et al. 2004; Pichavant et al. 2014) According to Pichavant et al. (2014), olivine started crystallizing at $1150-1200{ }^{\circ} \mathrm{C}$ and was joined on the liquidus by clinopyroxene at $1150{ }^{\circ} \mathrm{C}$; these temperatures are broadly in agreement with glass inclusion homogenization temperatures determined by Marianelli et al. (1995) and Cioni et al. (1998). Further melt evolution was dominated by clinopyroxene crystallization, as shown by a decrease in $\mathrm{CaO} / \mathrm{Al}_{2} \mathrm{O}_{3}$ ratios with decreasing $\mathrm{MgO}$ contents (c.f. Marianelli et al. 1995, 2005; Belkin et al. 1998; Raia et al. 2000; Piochi et al. 2006). Marianelli et al. (1999) found that phonotephrite magmas of the 1944 eruption of Vesuvius evolved by fractionation of the assemblage clinopyroxene + leucite + plagioclase + rare olivine. The importance of clinopyroxene is consistent with the experimental results of Pichavant et al. (2014), who showed that more than $35 \%$ clinopyroxene crystallized before the appearance of a second solid phase, especially at lower melt water contents.

The compositional data for the matrix glasses provide a guide to potential lower-pressure fractionation trends (Fig. 11). With decreases in $\mathrm{MgO}$ content from 7 to $3 \mathrm{wt} . \%$, there are decreases in $\mathrm{CaO}$ and modest increases in $\mathrm{SiO}_{2}$, $\mathrm{Al}_{2} \mathrm{O}_{3}$ and $\mathrm{Na}_{2} \mathrm{O}$; these trends are broadly parallel to those for the experimental glass compositions of Pichavant et al. (2014) and are consistent with the removal of clinopyroxene and olivine. The behaviour of $\mathrm{K}_{2} \mathrm{O}$ is more complex; between 3 and 4 wt.\% $\mathrm{MgO}, \mathrm{K}_{2} \mathrm{O}$ abundances in the glasses are generally lower than in more magnesian rocks and in the experimental glasses. This may be ascribed either to leucite fractionation and/or to loss of potassium during seondary hydration of the glasses. Iron, $\mathrm{TiO}_{2}$ and $\mathrm{P}_{2} \mathrm{O}_{5}$ show peaked trends, reaching maximum values at $\mathrm{MgO}$ values $\sim 3$ wt. $\%$, where Fe-Ti-oxides and apatite can be assumed to have joined the phenocryst assemblage. At the same point, the $\mathrm{SiO}_{2}$ trend steepens, also attesting to oxide crystallization. The increase in $\mathrm{K}_{2} \mathrm{O}$ content in the interval 3 to $0 \mathrm{wt} . \% \mathrm{MgO}$ is consistent with leucite leaving the fractionating assemblage.

\section{Phase equilibrium constraints}

Phase equilibrium studies of simplified model systems and of K-rich rocks can provide information on magmatic crystallization trends at Vesuvius and can help to constrain the $P-T$ $f \mathrm{O}_{2}-p \mathrm{H}_{2} \mathrm{O}$ conditions of crystallization. Discussion here is focussed on a study of model potassic systems by Nag et al. (2007) and on an experimental study of Vesuvius rocks by Pichavant et al. (2014).

Nag et al. (2007) determined the phase relationships in the model system Forsterite-Diopside-Leucite at 0.1 and $2.3 \mathrm{GPa}$ under water-saturated conditions. The phase boundaries are not directly applicable to Vesuvius because the starting materials did not contain $\mathrm{Fe}, \mathrm{Na}$ and $\mathrm{Ti}$. For instance, at $0.1 \mathrm{GPa}$ (Figs. 13a), the rocks plot in the olivine primary phase field, despite being olivine-clinopyroxene-leucite-plagioclasephyric. The sequence of phenocryst appearance is, however, consistent with the phase equilibria, as shown by the hypothetical crystallization path depicted as the solid line from initial composition X. Initial olivine formation is followed 
Table 6 Whole-rock compositions

\begin{tabular}{|c|c|c|c|c|c|c|c|c|c|c|}
\hline \multirow[b]{2}{*}{ Sample } & \multicolumn{8}{|c|}{ no phlogopite phenocrysts } & \multicolumn{2}{|c|}{ phlogopite-phyric } \\
\hline & L1 & $\mathrm{V} 1$ & L3 & $\mathrm{V} 3$ & $\mathrm{~L} 1$ & Vo1 bis $b$ & Vol bis d & Vo $2 \mathrm{f}$ & VX & $\mathrm{L} 2 \mathrm{~h}$ \\
\hline $\begin{array}{l}\text { TAS } \\
\text { wt.\% }\end{array}$ & pt & pt & $\mathrm{pt} / \mathrm{bt}$ & bt & pt & bt & bt & bt & pt & bt \\
\hline $\mathrm{SiO}_{2}$ & 51.60 & 50.22 & 50.48 & 50.09 & 50.74 & 50.45 & 50.30 & 50.45 & 47.69 & 51.47 \\
\hline $\mathrm{TiO}_{2}$ & 0.96 & 0.89 & 0.91 & 0.95 & 0.86 & 0.84 & 0.87 & 0.91 & 0.98 & 0.91 \\
\hline $\mathrm{Al}_{2} \mathrm{O}_{3}$ & 17.95 & 16.45 & 16.14 & 15.66 & 17.26 & 15.87 & 15.83 & 18.20 & 17.71 & 17.02 \\
\hline $\mathrm{Fe}_{2} \mathrm{O}_{3} *$ & 7.41 & 7.61 & 7.56 & 8.02 & 7.07 & 7.41 & 7.36 & 7.65 & 8.52 & 8.17 \\
\hline $\mathrm{MnO}$ & 0.12 & 0.12 & 0.13 & 0.13 & 0.13 & 0.12 & 0.13 & 0.13 & 0.15 & 0.14 \\
\hline $\mathrm{MgO}$ & 4.26 & 5.85 & 6.03 & 6.59 & 5.14 & 6.41 & 6.05 & 5.69 & 4.15 & 3.88 \\
\hline $\mathrm{CaO}$ & 8.06 & 9.26 & 9.63 & 9.96 & 8.51 & 9.52 & 9.41 & 9.23 & 9.55 & 8.73 \\
\hline $\mathrm{Na}_{2} \mathrm{O}$ & 2.24 & 2.01 & 1.85 & 1.89 & 2.03 & 1.85 & 1.89 & 2.14 & 2.74 & 2.75 \\
\hline $\mathrm{K}_{2} \mathrm{O}$ & 6.00 & 5.99 & 5.82 & 5.12 & 6.85 & 6.01 & 6.24 & 5.53 & 6.28 & 5.09 \\
\hline $\mathrm{P}_{2} \mathrm{O}_{5}$ & 0.68 & 0.67 & 0.70 & 0.71 & 0.59 & 0.61 & 0.62 & 0.70 & 0.81 & 0.60 \\
\hline LOI & 0.2 & 0.4 & 0.2 & 0.3 & 0.4 & 0.5 & 0.9 & 0.9 & 0.8 & 0.8 \\
\hline Sum & 99.48 & 99.47 & 99.45 & 99.42 & 99.58 & 99.59 & 99.60 & 101.53 & 99.38 & 99.56 \\
\hline \multicolumn{11}{|l|}{ ppm } \\
\hline Co & 23.6 & 28.5 & 28 & 31.6 & 25.4 & 33.1 & 27.3 & 25.9 & 28.2 & 22.7 \\
\hline $\mathrm{Ni}$ & 19.1 & 25.4 & 29.3 & 32.0 & 28.7 & 37.2 & 26.2 & 30.9 & 7.0 & 6.8 \\
\hline $\mathrm{Sc}$ & 23 & 27 & 29 & 32 & 22 & 27 & 27 & 25 & 16 & 17 \\
\hline V & 214 & 217 & 218 & 232 & 200 & 210 & 189 & 194 & 229 & 196 \\
\hline $\mathrm{Ba}$ & 1605 & 1741 & 1733 & 1722 & 1587 & 1486 & 1509 & 1653 & 2336 & 1303 \\
\hline Cs & 12.6 & 13.9 & 13.5 & 10.5 & 20.0 & 14.4 & 15.4 & 11.3 & 17.5 & 11.6 \\
\hline $\mathrm{Rb}$ & 263 & 275 & 257 & 210 & 314 & 280 & 298 & 236 & 260 & 248 \\
\hline $\mathrm{Sr}$ & 843 & 874 & 867 & 846 & 717 & 762 & 719 & 791 & 1129 & 854 \\
\hline $\mathrm{La}$ & 42.6 & 41.3 & 43.2 & 44.2 & 37.0 & 36.6 & 36.9 & 41.0 & 53.3 & 49.2 \\
\hline $\mathrm{Ce}$ & 91.5 & 90.6 & 93.1 & 94.9 & 72.7 & 72.2 & 76.9 & 84.1 & 114.9 & 93.5 \\
\hline $\operatorname{Pr}$ & 11.00 & 10.70 & 10.95 & 11.43 & 8.66 & 8.87 & 8.91 & 9.94 & 13.60 & 11.32 \\
\hline $\mathrm{Nd}$ & 44.9 & 42.2 & 43.0 & 45.5 & 35.2 & 35.2 & 35.6 & 41.0 & 52.0 & 47.7 \\
\hline $\mathrm{Sm}$ & 8.46 & 8.36 & 8.81 & 8.84 & 6.64 & 7.10 & 7.62 & 7.61 & 10.55 & 9.09 \\
\hline $\mathrm{Eu}$ & 1.96 & 1.97 & 2.03 & 2.21 & 1.72 & 1.85 & 1.78 & 1.85 & 2.54 & 2.09 \\
\hline Gd & 6.45 & 6.72 & 6.74 & 7.45 & 6.04 & 6.20 & 6.54 & 6.50 & 8.12 & 7.74 \\
\hline $\mathrm{Tb}$ & 0.94 & 0.97 & 0.99 & 1.05 & 0.71 & 0.80 & 0.79 & 0.82 & 1.16 & 0.96 \\
\hline Dy & 4.67 & 4.39 & 4.60 & 4.85 & 3.75 & 3.95 & 4.65 & 4.60 & 5.32 & 5.17 \\
\hline Но & 0.82 & 0.88 & 0.80 & 0.88 & 0.72 & 0.69 & 0.79 & 0.74 & 0.95 & 0.82 \\
\hline $\mathrm{Er}$ & 2.21 & 2.27 & 2.22 & 2.51 & 1.78 & 1.84 & 1.76 & 1.90 & 2.67 & 2.77 \\
\hline $\mathrm{Tm}$ & 0.34 & 0.34 & 0.31 & 0.33 & 0.25 & 0.26 & 0.24 & 0.29 & 0.37 & 0.38 \\
\hline $\mathrm{Yb}$ & 1.94 & 2.09 & 1.99 & 2.12 & 1.54 & 1.65 & 1.76 & 1.76 & 2.24 & 2.32 \\
\hline $\mathrm{Lu}$ & 0.31 & 0.30 & 0.30 & 0.30 & 0.23 & 0.23 & 0.23 & 0.26 & 0.32 & 0.34 \\
\hline Y & 24.3 & 24.2 & 24.4 & 26.0 & 19.7 & 21.3 & 21.2 & 23.1 & 27.9 & 26.0 \\
\hline $\mathrm{Cu}$ & 60 & 81 & 35 & 71 & 74 & 93 & 272 & 183 & 27 & 26 \\
\hline $\mathrm{Pb}$ & 50.8 & 18.3 & 200.4 & 15.6 & 7.7 & 4.9 & 2.1 & 15.9 & 64.7 & 3.3 \\
\hline $\mathrm{Zn}$ & 52 & 29 & 36 & 27 & 34 & 40 & 29 & 38 & 35 & 35 \\
\hline $\mathrm{Ga}$ & 17.0 & 15.8 & 15.3 & 15.2 & 17.4 & 14.3 & 13.6 & 14.3 & 17.5 & 18.4 \\
\hline $\mathrm{Zr}$ & 217.1 & 181.1 & 178.8 & 191.0 & 166.6 & 165.8 & 168.7 & 184.2 & 184.4 & 230.8 \\
\hline Hf & 5.7 & 4.3 & 4.4 & 4.8 & 3.7 & 4.7 & 4.6 & 4.3 & 4.4 & 5.3 \\
\hline $\mathrm{Nb}$ & 35.9 & 27.0 & 26.2 & 27.5 & 23.0 & 22.0 & 23.0 & 25.0 & 29.6 & 35.0 \\
\hline $\mathrm{Ta}$ & 1.9 & 1.4 & 1.3 & 1.4 & 1.2 & 1.0 & 1.0 & 1.2 & 1.7 & 1.9 \\
\hline Th & 20.8 & 15.7 & 15.4 & 15.9 & 13.9 & 11.9 & 12.1 & 14.4 & 21.0 & 15.3 \\
\hline $\mathrm{U}$ & 8.7 & 4.8 & 4.8 & 5.3 & 4.4 & 3.9 & 3.8 & 4.6 & 7.1 & 4.8 \\
\hline $\mathrm{Mg} \#$ & 53 & 60 & 61 & 62 & 59 & 63 & 62 & 60 & 49 & 48 \\
\hline $\mathrm{CaO} / \mathrm{Al}_{2} \mathrm{O}_{3}$ & 0.45 & 0.56 & 0.60 & 0.64 & 0.49 & 0.60 & 0.59 & 0.51 & 0.54 & 0.51 \\
\hline
\end{tabular}

$\mathrm{Fe}_{2} \mathrm{O}_{3}{ }^{*}$, all $\mathrm{Fe}$ as $\mathrm{Fe}^{3+} . \mathrm{Mg} \#=$ magnesium-number $\left(\mathrm{Mg} /\left(\mathrm{Mg}+\mathrm{Fe}^{2+}\right)\right)$. pt, phonotephrite; bt, basaltic trachyandesite TAS, classification on total alkalis-silica plot (Le Bas et al. 1986) 

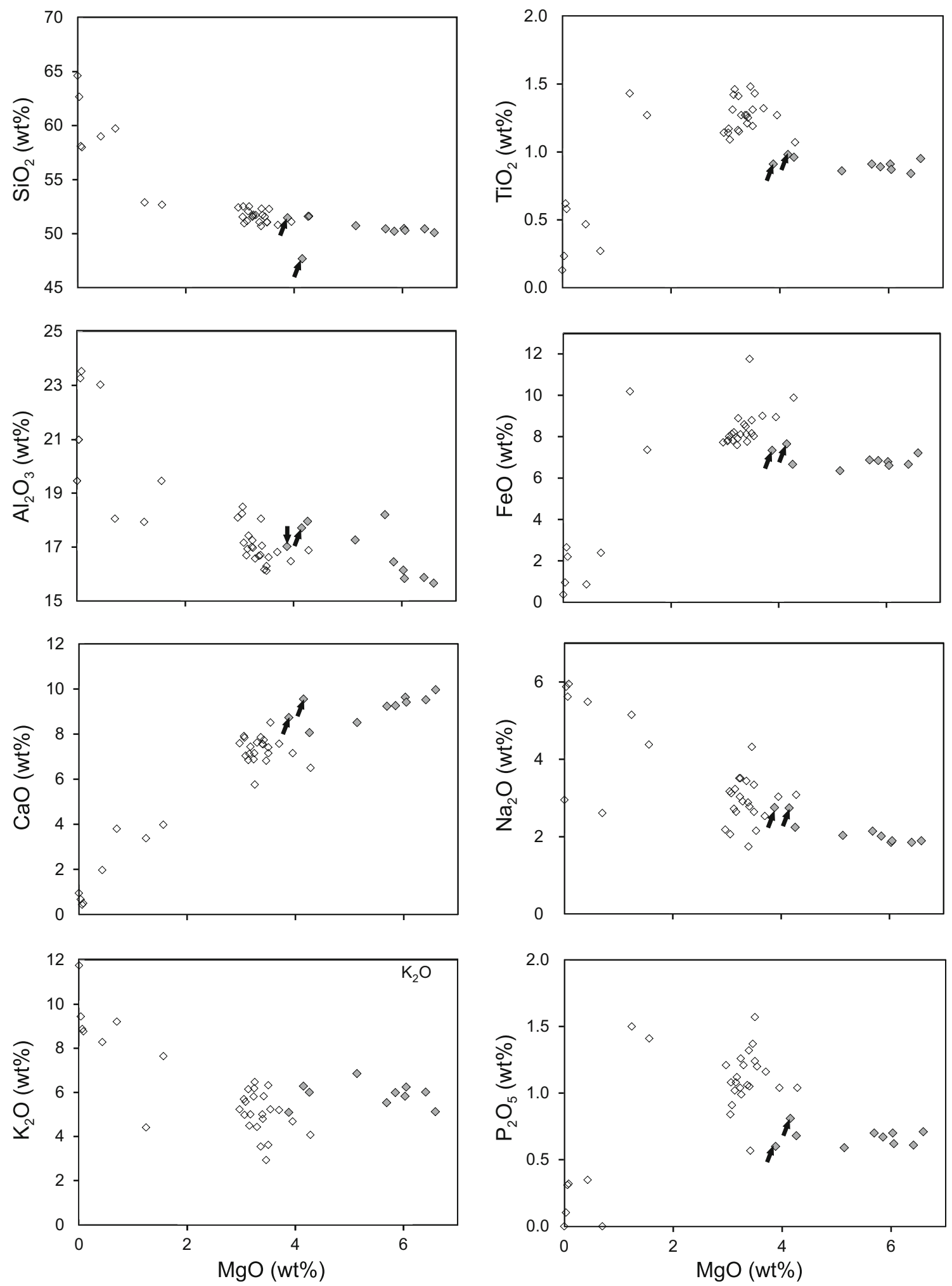

Fig. 11 Major elements (as oxides; wt.\%) plotted against $\mathrm{MgO}$ for whole-rocks and matrix glasses. The black arrows point to phlogopite-phyric samples. Data from Table 6 and Supplementary Table 5

by olivine + clinopyroxene crystallization along the cotectic until the 5-phase point olivine + clinopyroxene + leucite + melt+vapour is reached at $880{ }^{\circ} \mathrm{C}$. Precipitation of all three minerals continues until the temperature drops to $\sim 830{ }^{\circ} \mathrm{C}$ when phlogopite appears (Nag et al. 2007, Table 1). This sequence partially reproduces the phenocryst assemblage in 


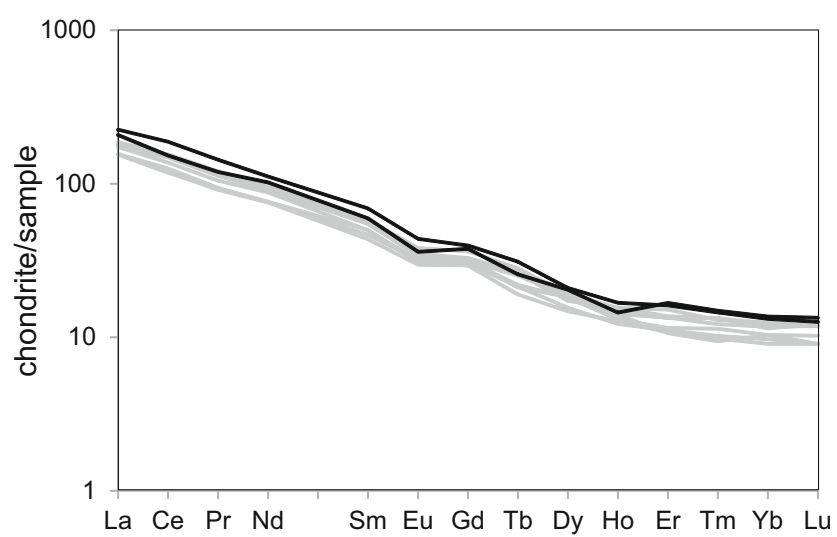

Fig. 12 Chondrite-normalised REE patterns. Solid black lines are for phogopite-phyric rocks (VX and L2h), the grey lines for rocks lacking phlogopite phenocrysts. The patterns are generally very similar, although the phlogopite-phyric rocks have slightly higher LREE contents and LREE/HREE ratios. Data from Table 6. Normalising factors from Sun and McDonough (1989)

the Type 1 rocks, but predicts that phlogopite would crystallize before the observed plagioclase. Phlogopite is present in the matrix of Type 1 rocks but clearly postdated the plagioclase. Neither does the sequence fully represent the crystallization path of the phlogopite-phyric phonotephrites, since it places phlogopite too near the solidus (contrast the relationships in Fig. 3c). As an alternative, let us assume that crystallization of anhydrous phases raised the water content of residual melts sufficiently that a higher $p \mathrm{H}_{2} \mathrm{O}$ is appropriate or that the phlogopite-phyric rocks were derived from parental magmas with higher melt water contents.

At $2.3 \mathrm{GPa}$, leucite is no longer stable and a stability field for phlogopite separates the olivine field from those of sanidine and kalsilite (Fig. 13b). Ignoring leucite for the moment, we can infer that the Vesuvius magmas evolved along a natural olivine-clinopyroxene cotectic analogous to that in the phase diagram until they reached a point (B) when phlogopite began to form and olivine began to be resorbed. Olivine resorption is consistent with textural evidence in the rocks. When all olivine had disappeared, melts migrated down the clinopyroxene-phlogopite cotectic; they did not, however, reach the lower-temperature reaction point at $990{ }^{\circ} \mathrm{C}$, since kalsilite is not a phenocryst phase. Sample VX contains leucite microphenocrysts whilst $\mathrm{L} 2 \mathrm{~h}$ is plagioclase-phyric (Table 1). This may reflect their different $\mathrm{Na}_{2} \mathrm{O} / \mathrm{K}_{2} \mathrm{O}$ ratios, 0.44 and 0.54 , respectively.

In summary, the Nag et al. (2007) phase equilibria are compatible with the phenocryst assemblages in the Type 1 rocks having last equilibrated at very low pressures $(\sim 0.1 \mathrm{GPa})$; whereas the phlogopite-phyric magmas appear to record rather higher pressures ( $\sim 2-3 \mathrm{GPa})$.

Pichavant et al. (2014) conducted experiments on two Vesuvius rocks (a tephrite and a trachybasalt) at high temperatures $\left(1000\right.$ to $\left.>1200{ }^{\circ} \mathrm{C}\right)$, at both low $(0.1 \mathrm{MPa})$ and
Table 7 Representative compositions of matrix glass and melt inclusions

\begin{tabular}{|c|c|c|c|c|c|c|c|c|}
\hline \multirow[b]{2}{*}{ Sample } & \multicolumn{5}{|c|}{ Matrix glasses } & \multicolumn{3}{|c|}{ Melt inclusions } \\
\hline & V1 M & V3 & V3 & L1 & VX & Volbisb & Volbisb & VX \\
\hline TAS & bt & $\mathrm{pt}$ & bt & $\operatorname{tr}$ & $\mathrm{ph}$ & pt & tp & $\mathrm{ph}$ \\
\hline \multicolumn{9}{|l|}{ wt. $\%$} \\
\hline $\mathrm{SiO}_{2}$ & 51.62 & 51.75 & 52.31 & 64.61 & 57.99 & 52.14 & 52.31 & 58.99 \\
\hline $\mathrm{TiO}_{2}$ & 1.07 & 1.15 & 1.21 & 0.13 & 0.58 & 1.40 & 1.15 & 0.47 \\
\hline $\mathrm{Al}_{2} \mathrm{O}_{3}$ & 16.88 & 16.97 & 18.05 & 19.45 & 23.52 & 18.04 & 18.99 & 23.02 \\
\hline $\mathrm{FeO}^{*}$ & 9.88 & 8.89 & 8.12 & 0.37 & 2.20 & 6.73 & 7.47 & 0.86 \\
\hline $\mathrm{MnO}$ & 0.12 & 0.20 & 0.25 & bd & bd & 0.13 & 0.18 & bd \\
\hline $\mathrm{MgO}$ & 4.28 & 3.25 & 3.40 & bd & 0.08 & 1.34 & 1.54 & 0.43 \\
\hline $\mathrm{CaO}$ & 6.50 & 5.76 & 7.54 & 0.95 & 0.50 & 4.68 & 3.80 & 1.97 \\
\hline $\mathrm{Na}_{2} \mathrm{O}$ & 3.08 & 3.51 & 1.74 & 2.95 & 5.95 & 3.28 & 3.22 & 5.49 \\
\hline $\mathrm{K}_{2} \mathrm{O}$ & 4.07 & 6.47 & 4.80 & 11.75 & 8.76 & 6.88 & 7.92 & 8.28 \\
\hline $\mathrm{BaO}$ & 0.43 & bd & 0.29 & bd & 0.14 & & & \\
\hline $\mathrm{P}_{2} \mathrm{O}_{5}$ & 1.04 & 0.99 & 1.05 & bd & 0.32 & 1.22 & 1.34 & 0.35 \\
\hline $\mathrm{Cl}$ & 0.10 & 0.19 & 0.18 & 0.03 & 0.42 & 0.18 & 0.20 & 1.03 \\
\hline Sum & 99.07 & 99.13 & 98.94 & 100.24 & 100.46 & 96.02 & 98.12 & 100.89 \\
\hline $\mathrm{O} \equiv \mathrm{Cl}$ & 0.02 & 0.04 & 0.04 & 0.01 & 0.10 & 0.04 & 0.05 & 0.24 \\
\hline Total & 99.05 & 99.09 & 98.90 & 100.23 & 100.36 & 95.98 & 98.07 & 100.65 \\
\hline
\end{tabular}

TAS, classification on total alkalis-silica plot (Le Bas et al. 1986)

$b t$ basaltic trachyandesite, $p h$ phonolite, $p t$ phonotephrite, $t p$ tephriphonolite, $t r$ trachyte

bd, not detected. Blank, not determined. $\mathrm{FeO}^{*}$, all $\mathrm{Fe}$ as $\mathrm{Fe}^{2+}$. Mineral hosts for melt inclusions are given in Supplementary Table 5a 

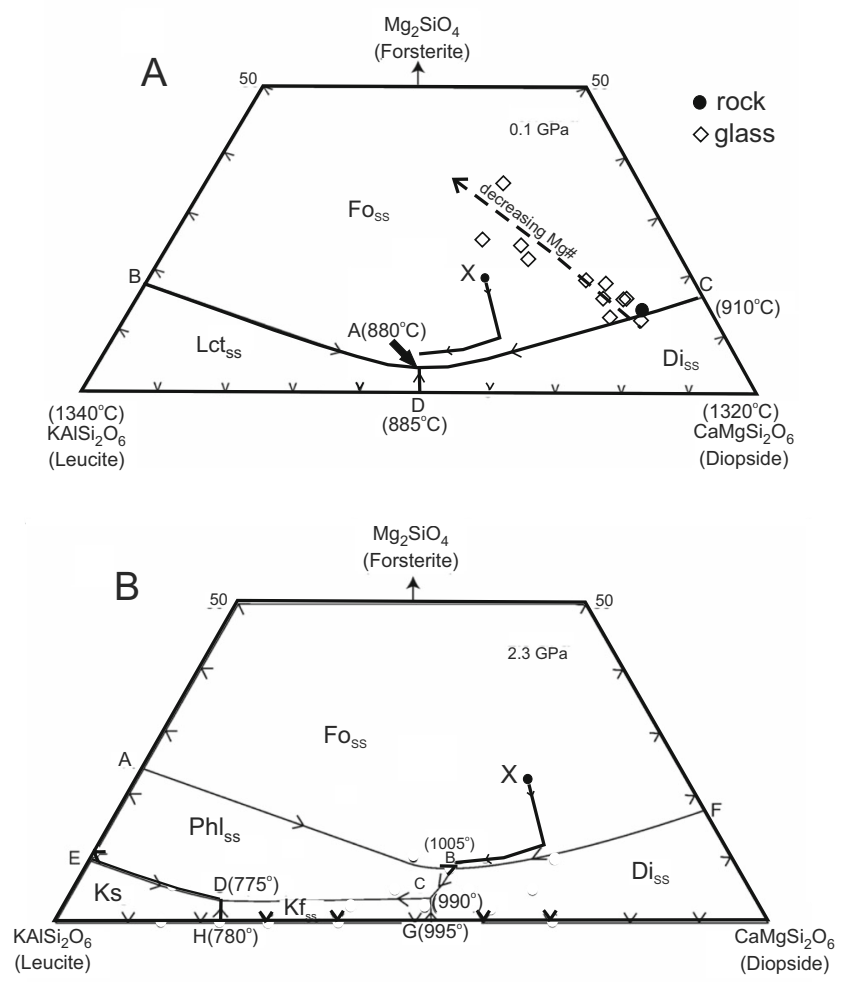

Fig. 13 a Phase relationships in the system Forsterite (Fo)-Diopside (Di)-Leucite (Lc) determined at $0.1 \mathrm{GPa}$ pressure under water-saturated conditions by Nag et al. (2007). The solid line represents the melt path of an initial bulk composition (X) plotting in the olivine primary phase field. The inferred sequence of appearance of the solid phases (olivine $\rightarrow$ olivine + clinopyroxene $\rightarrow$ olivine + clinopyroxene + leucite) is broadly compatible with the phenocryst assemblages from Type 1 rocks of this study. The leucite component was calculated from the relationship $\mathrm{KAlSi}_{3} \mathrm{O}_{8}=$ $\mathrm{KAlSi}_{2} \mathrm{O}_{6}+\mathrm{SiO}_{2}$. Also shown are the compositions of the initial rock and the experimental glasses from a Vesuvius trachybasalt (sample VS96-5A) determined by Pichavant et al. (2014). More evolved compositions, as

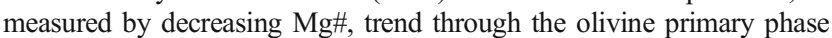
field, directly away from the diopside apex $\mathbf{b}$ Phase relationships in the same system at $2.3 \mathrm{GPa}$ pressure under water-saturated conditions (Nag et al. 2007). Ks, kalisilite; Kf, potassic feldspar. The crystallizing assemblages and melt path of the same initial bulk composition as in (a) are partly comparable to that of the phlogopite-phyric rocks (see text for details) and are at least consistent with those magmas having evolved at rather higher pressures

high (50-200 MPa) pressures, and under fluid-absent and fluid-present conditions, where the fluid contained $\mathrm{H}_{2} \mathrm{O}$ and $\mathrm{CO}_{2}$. The tephrite is clinopyroxene-leucite-plagioclase-phyric and has a $\mathrm{Mg \#}$ of 61.5 . The trachybasalt contains clinopyroxene-olivine-plagioclase-leucite phenocrysts and has a $\mathrm{Mg \#}$ of 64.3. Both rocks clearly have analogues in the rocks of the eccentric and parasitic cones (Table 1). Clinopyroxene was the liquidus phase in all experiments, followed by leucite for melt water contents $<3 \mathrm{wt} . \%$ and by phlogopite for melt water contents $>3 \mathrm{wt} . \%$. These results are broadly comparable to those of Nag et al. (2007). In contrast, olivine crystallized spontaneously from only one charge and plagioclase was not found at all. This is not consistent with evidence from the cone rocks, where olivine and plagioclase phenocrysts are common members of the Type 1 assemblage. Another contrasting feature with the natural rocks is that no 4-phase ( 3 solids + melt) assemblage was detected; yet assemblages with 4 and 5 solid phases are present in the rocks (Table 1).

The absence of an olivine stability field was also found in phase diagrams for rocks of the 1944 Vesuvius eruption determined by Dolfi and Trigila (1978). An unusual feature of the absence of olivine is that the melt (glass) compositions from the Pichavant et al. (2014) experiments, and the wholerock data of this study, trend across the olivine primary phase field in Fig. 13, directly away from the diopside apex.

Pichavant et al. (2014) cited two possible reasons for the absence of olivine. First, the rocks used in their experiments were not representative of primary magmas and therefore were too evolved to crystallize olivine. Second, assimilation of carbonate wall-rocks had expanded the field of clinopyroxene relative to olivine, such that the parental magmas entered into the clinopyroxene primary phase field. Jolis et al. (2013) demonstrated experimentally that the assimilation can happen on very short time-scales. The textural evidence of olivine resorption in the cones rocks suggests that it was close to its stability limit in magmas with $\mathrm{Mg} \# \sim 60$.

The absence of plagioclase in the Pichavant et al. (2014) experiments is apparently at odds with the petrographic evidence of plagioclase phenocrysts $\left(\mathrm{An}_{87-80}\right)$ in their sample VS96-54A, which has a Mg\# of 64. However, glass formed in excess of $50 \%$ of the experimental charges and it might be assumed that plagioclase would have crystallized at lower melt proportions. All the samples in this study, except VX, carry plagioclase phenocrysts (Table 1) but it generally crystallised later than the olivine, clinopyroxene and leucite. However, the occurrence of core compositions of composition An $>90$ points to early crystallization in at least the L2h magma. The late crystallization of plagioclase in Vesuvius magmas has been alluded to by Marianelli et al. (1999), Lima et al. (2003) and Santacroce et al. (2008). It is uncertain what "late" means in this context. Marianelli et al. (1999), for example, refer to plagioclase being present in the assemblage fractionating from 1944 phonotephrites and it is present in the phonotephrites in the cones. Late crystallization of plagioclase would leave unresolved the fact that negative Eu anomalies are a very common feature of basic Vesuvius rocks; for example, sample V44 T3 in Villemant et al. (1993, p.297), with a Mg\# of 71, has a significant negative Eu anomaly $\left(E u / E u^{*}=0.77\right)$. Such anomalies are commonly ascribed to plagioclase fractionation.

\section{Pressure of crystallization and melt water contents}

Experimental evidence from the system Quartz-NephelineKalsilite indicates, for example, that the formation of 
phenocrystic leucite in the Vesuvius rocks took place at pressures below 0.1 GPa (Fudali 1963; Hamilton and MacKenzie 1965; Zeng and MacKenzie 1984; Gupta et al. 2010). Since the phonotephrites crystallized early olivine and clinopyroxene, pointing to a smaller stability field for leucite at higher temperatures, the magmas may actually have crystallized at pressures of no more than a few tens of MPa, as suggested by Henderson et al. (2012) for phonotephrites (mafic phonolites) of the Highwood Mountains, Montana. The experimental results of Nag et al. (2007) and Pichavant et al. (2014) also indicate that leucite is stable only at low pressures.

In their high P-T experiments on Vesuvius rocks, Pichavant et al. (2014) found that the experimental clinopyroxenes formed two groups. In fluid-present (lower melt water content) and 0.1 MPa charges, Wo decreases with increasing $\mathrm{Al}_{2} \mathrm{O}_{3}$ (Fig. 14), whereas in the fluid-absent (higher melt water content) charges Wo increases along with increasing $\mathrm{Al}_{2} \mathrm{O}_{3}$ (Fig. 14). They suggested that natural Vesuvius clinopyroxenes follow the $\mathrm{H}_{2} \mathrm{O}$-rich trend. The clinopyroxenes in the parasitic and eccentric cones also follow the $\mathrm{H}_{2} \mathrm{O}$-rich ( $\left.>2 \mathrm{wt} . \%\right)$ trend (Fig. 14). There is also a slight difference between the plotted positions on the phlogopite-phyric and phlogopite-aphyric rocks, the latter plotting to higher Wo values for a given $\mathrm{Al}_{2} \mathrm{O}_{3}$ content. This is consistent with their having slightly higher melt water contents; in the Pichavant et al. (2014) experiments, phlogopite became the third phase, replacing leucite, at $1050{ }^{\circ} \mathrm{C}$ and melt water content of 5.1-6.0 wt.\%.

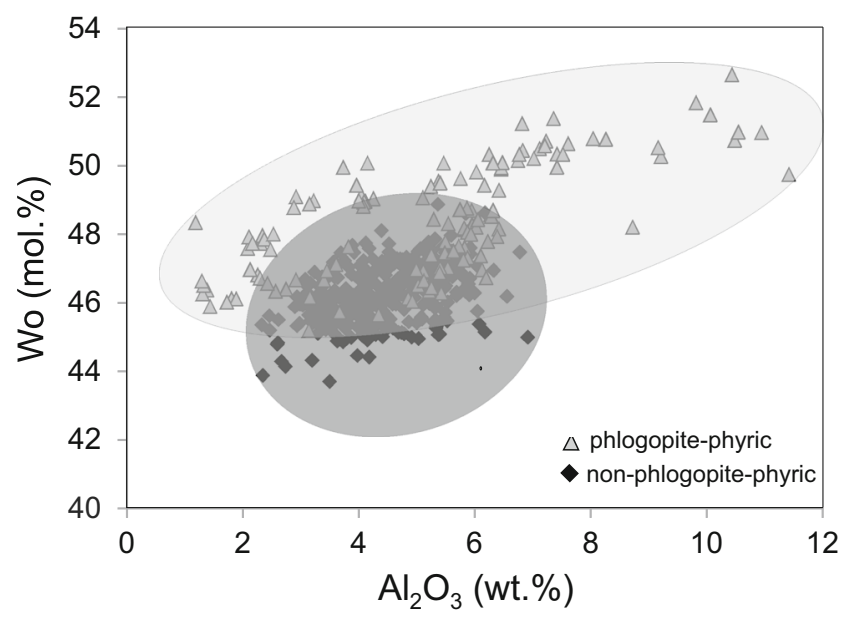

Fig. 14 Wo- $\mathrm{Al}_{2} \mathrm{O}_{3}$ plot for clinopyroxene phenocrysts. Pichavant et al. (2014) determined that clinopyroxenes crystallized in their fluid-absent, water-rich $\left(>2 \mathrm{wt} . \% \mathrm{H}_{2} \mathrm{O}\right)$ experiments followed a positive trend on this plot, whereas clinopyroxenes from fluid-present, water-poor $(<2 \mathrm{wt} . \%$ $\mathrm{H}_{2} \mathrm{O}$ ) experiments showed a negative correlation. Natural Vesuvius clinopyroxenes follow a positive trend. Samples from the eccentric and parasitic cones also follow this trend. Clinopyroxenes from phlogopitephyric rocks (VX and L2h) generally plot at higher Wo contents (for a given $\mathrm{Al}_{2} \mathrm{O}_{3}$ content) than rocks lacking phlogopite phenocrysts, consistent with their magmas having had higher melt water contents. Data from Supplementary Table 2. Wo calculated with all $\mathrm{Fe}$ as $\mathrm{Fe}^{2+}$

\section{Role of magma mixing}

The clinopyroxene phenocrysts show many disequilibrium growth features, including the presence of magnesian cores (Mg\# $>90)$ surrounded by variously zoned (oscillatory, sector, concentric) mantle of more Fe-rich compositions. Many phenocrysts contain abundant, irregularly shaped melt and matrix inclusions. Such disequilibrium textures have been interpreted at Vesuvius as being the result of magma mixing (Cioni et al. 1998; Landi et al. 1999; Marianelli et al. 1999; Fulignati et al. 2004). The mixing is more difficult to discern in the wholerock compositions, in that it has tended to occur between magmas along one, or similar, liquid lines of descent.

In summary, it is often difficult to describe in detail the evolution of Vesuvius magmas. Geochemical trends are obscured by the multi-lineage nature of the parental magmas, by selective crystal accumulation or removal and by magma mixing. Experimental studies have had only partial success

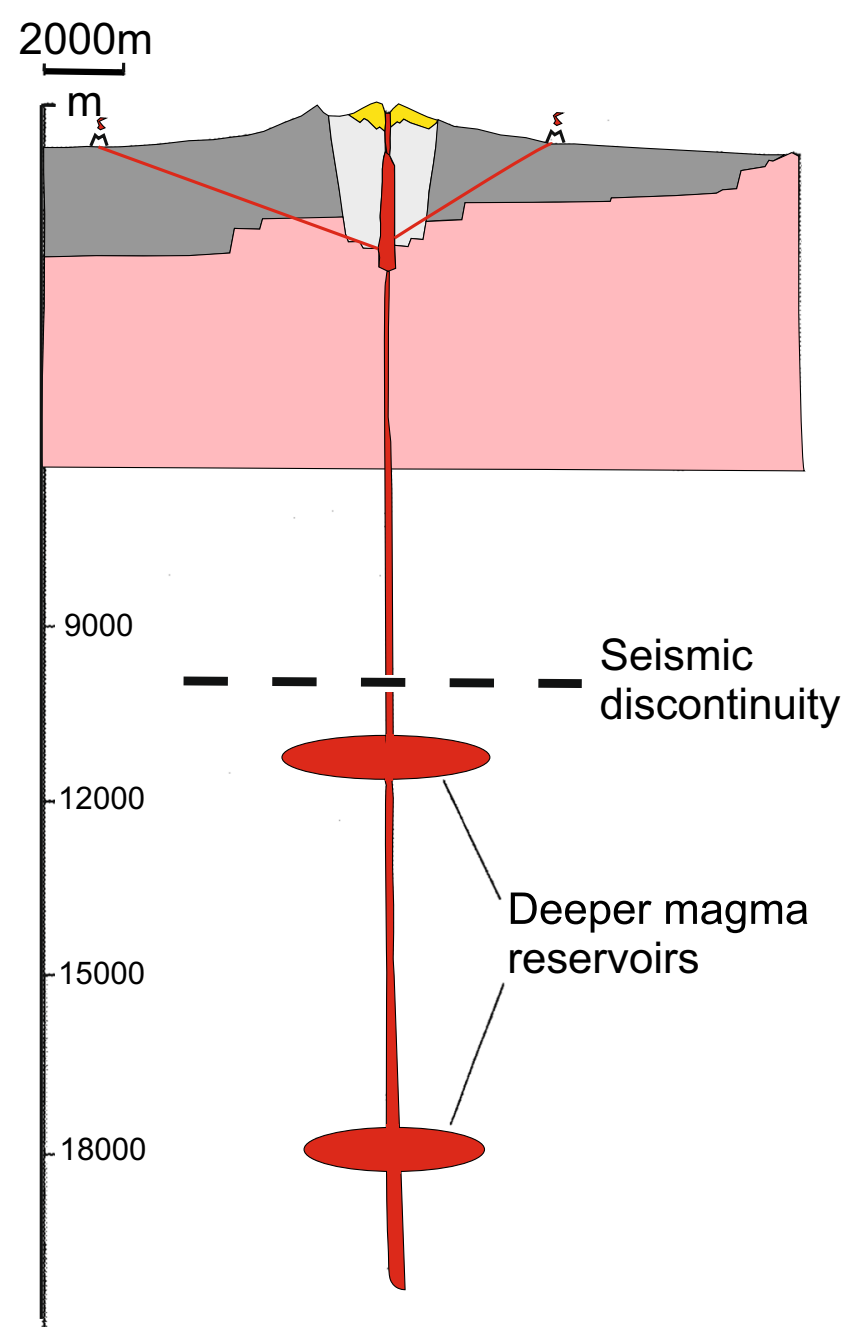

Fig. 15 Schematic cross-section through Somma-Vesuvius, broadly based on Marianelli et al. (1995). The solid lines represent possible conduits for the eccentric and parasitic cone magmas, emanating from a chamber at $\sim 2-3 \mathrm{~km}$ depth 
in reproducing the complex textural relationships and, in particular, the sequence of phenocryst assemblages, which are commonly disequilibrium assemblages. An added complication is that the Vesuvius plumbing system is a dynamic crystallization environment, with varying $f \mathrm{O}_{2}, P$ and $p \mathrm{H}_{2} \mathrm{O}$. Comparing eruptive products belonging to different, even closely spaced, episodes is not easy. The role of pressure in allowing magmas to cross phase boundaries has not yet been fully explored experimentally. Nevertheless, all available geochemical and phase equilibrium data indicate that the evolution of any given eruptive sequence is dominated by massive clinopyroxene fractionation.

\section{The Somma-Vesuvius plumbing system}

There has been some uncertainty about the nature of the magmatic plumbing system of Somma-Vesuvius. The view established in the early 1980s that a shallow-level magma chamber ( 3-6 km depth) existed beneath the volcano (Barberi and Leoni 1980; Barberi et al. 1981) was challenged by Belkin et al. (1985) and Belkin and De Vivo (1993), who showed, from the study of fluid inclusions in clinopyroxene, olivine and spinel from a nodule suite, that the crystallization depths of minerals hosting $\mathrm{CO}_{2}$-bearing inclusions occurred at depths of $3.5-10 \mathrm{~km}$ and $>12 \mathrm{~km}$. No evidence was found for a shallow trapping depth. The recognition of deeper magma chambers was subsequently confirmed by seismic tomographic studies, which identified a horizontal, regionally extensive lowvelocity layer whose top lies at $8 \mathrm{~km}$ beneath the volcano (Zollo et al. 1998; Auger et al. 2001). Seismic (Auger et al. 2001) and magnetotelluric (Di Maio et al. 1998) evidence was interpreted as pointing to a large magma reservoir at depths of $\sim 8-10 \mathrm{~km}$.

Recent models of the plumbing system largely favour the presence of deep and shallow reservoirs, the system covering the depth range $\geq 20$ to $2 \mathrm{~km}$ (Santacroce et al. 1993; Marianelli et al. 1995, 1999, 2005; Cioni et al. 1998; De Natale et al. 2001; Lima et al. 2003; Civetta et al. 2004; Fulignati et al. 2004; Di Renzo et al. 2007). The detailed structure of the plumbing system is debatable: for example, Lima et al. (2003) viewed it as a complex feeding chamber dominated by a multiple mush zone of small chambers. On the basis of experimental phase equilibria, Scaillet et al. (2008) proposed that the ponding level feeding eruptive activity has migrated upwards in the last $18.5 \mathrm{kyr}$ by $9-11 \mathrm{~km}$ and is currently at a depth of 3-4 km. In the deeper reservoirs, primary tephritic magmas evolve by fractional crystallization to phonotephrites, which then ascend to shallow reservoirs where they mix with the resident magma and/or undergo further fractionation, producing more evolved magma types.

The presence of leucite phenocrysts in the rocks of the parasitic and eccentric cones indicates that the magmas crystallized at shallow pressures, perhaps as low as a few tens of $\mathrm{MPa}$. It is highly likely that they were emplaced from a very shallow part of the plumbing system and thus were emplaced essentially laterally. According to Acocella et al. (2006), the nature of the emplacement of dykes at Vesuvius between 1631 and 1944 was dependent on the opening or closure of the summit conduit. When the conduit was closed, the dykes propagated vertically and related fissures propagated upslope. This probably occurred mainly around the central cone, above the reservoir. When the conduit was open, the dykes radiated from the summit and the fissures propagated downslope; during these stages, no vent opened beyond $5 \mathrm{~km}$ from the summit. The eccentric cones occur at distances of 5-8 km from the summit. Accordingly, we have drawn them in Fig. 15 as propagating laterally from a shallow reservoir.

Acknowledgments We thank Alok Krishna Gupta, Silvio Mollo, Bruno Scaillet and Roberto Sulpizio for very detailed and constructive reviews of the manuscript. We also thank Piotr Dzierżanowski and Lidia Jeżak for help with electron microprobe analyses. Financial support was provided by University of Warsaw grant no. BSt 173504 IGMiP 39-2015.

\section{New Pollena samples}

In a Pollena quarry, the sampling of small cones was as follows:-

I cone (coordinates: $40^{\circ} 50^{\prime} 44^{\prime \prime} \mathrm{N} ; 14^{\circ} 23^{\prime} 32^{\prime \prime} \mathrm{E}$ (or $40.84568 \mathrm{~N} ; 14.39241 \mathrm{E}$ ) at altitude $256 \mathrm{~m}$ asl. Samples are labelled Vo1 bis a, b, c, d and L1(bis e). Sample a was on the western side, sample b on the southern side, $\mathrm{c}, \mathrm{d}$, e on the western side.

II cone (coordinates: $40^{\circ} 50^{\prime} 40^{\prime \prime} \mathrm{N}$; $14^{\circ} 23^{\prime} 36^{\prime \prime} \mathrm{E}$ (or $40.84454 \mathrm{~N} ; 14.39352 \mathrm{E}$ ) at altitude $282 \mathrm{~m}$ asl. Samples are labelled Vo2 (f, g) and L2 (h).

III cone (coordinates: $40^{\circ} 50^{\prime} 36^{\prime \prime} \mathrm{N} ; 1^{\circ} 23^{\prime} 41^{\prime \prime} \mathrm{E}$ (or $40.84346 \mathrm{~N} ; 14.39484 \mathrm{E})$ at altitude $325 \mathrm{~m}$ asl. Samples are Vo3 and L3.

Open Access This article is distributed under the terms of the Creative Commons Attribution 4.0 International License (http:// creativecommons.org/licenses/by/4.0/), which permits unrestricted use, distribution, and reproduction in any medium, provided you give appropriate credit to the original author(s) and the source, provide a link to the Creative Commons license, and indicate if changes were made.

\section{References}

Acocella V, Porreca M, Neri M, Mattei M (2006) Fissure eruptions at Mount Vesuvius (Italy): insights on the shallow propagation of dikes at volcanoes. Geology 34:673-676

Auger E, Gasparini P, Virieux J, Zollo A (2001) Seismic evidence of an extended magmatic sill under Mt. Vesuvius. Science 294: $1510-1512$

Ayuso RA, De Vivo B, Rolandi G, Seal R II, Paone A (1998) Geochemical and isotopic $(\mathrm{Nd}, \mathrm{Pb}, \mathrm{Sr}, \mathrm{O})$ variations bearing on 
the genesis of volcanic rocks from Vesuvius, Italy. J Volcanol Geotherm Res 82:53-78

Barberi F, Leoni L (1980) Metamorphic carbonate ejecta from Vesuvius plinian eruptions: evidence of the occurrence of shallow magma chambers. Bull Volcanol 43:107-120

Barberi F, Bizouard H, Clocchiatti R, Métrich N, Santacroce R, Sbrana A (1981) The Somma- Vesuvius magma chamber: a petrological and geochemical approach. Bull Volcanol 44:295-315

Belkin HE, De Vivo B (1993) Fluid inclusion studies of ejected nodules from plinian eruptions of Mt. Somma-Vesuvius. In: De Vivo, B, Scandone R, Trigila R (eds) Spec Issue J Volcanol Geotherm Res 58:89-100

Belkin HE, De Vivo B, Roedder E, Cortini M (1985) Fluid inclusion geobarometry from ejected Mt. Somma-Vesuvius nodules. Am Mineral 70:288-303

Belkin HE, Kilburn CRJ, De Vivo B (1993) Sampling and major element chemistry of the recent (A.D. 1631-1944) Vesuvius activity. J Volcanol Geotherm Res 58:273-290

Belkin HE, De Vivo B, Török K, Webster JD (1998) Pre-eruptive volatile content, melt-inclusion chemistry, and microthermometry of interplinian Vesuvius lavas (pre-A.D. 1631). J Volcanol Geotherm Res 82:79-95

Brocchini F, Principe C, Castradori D, Laurenzi MA, Goria L (2001) Quaternary evolution of the southern sector of the Campanian plain and early Somma-Vesuvius activity: insights from the Trecase well. Mineral Petrol 73:67-91

Cioni R, Marianelli P, Santacroce R (1998) Thermal and compositional evolution of the shallow magma chambers of Vesuvius: evidence from pyroxene phenocrysts and melt inclusions. J Geophys Res 103: $18277-18294$

Cioni R, Santacroce R, Sbrana A (1999) Pyroclastic deposits as a guide for reconstructing the multi-stage evolution of the Somma-Vesuvius caldera. Bull Volcanol 60:207-222

Civetta L, D’Antonio M, de Lorenzo S, Di Renzo V, Gasparini P (2004) Thermal and geochemical constraints on the 'deep' magmatic structure of Mt. Vesuvius. J Volcanol Geotherm Res 133:1-12

Deer WA, Howie RA, Zussman J (1997) Rock-forming minerals, vol 2A, second edn, Single-chain silicates. The Geological Society, London, p 668

Delaney JS, Smith JV, Carswell DA, Dawson JB (1980) Chemistry of micas from kimberlites and xenoliths - II. Primary- and secondarytextured micas from peridotite xenoliths. Geochim Cosmochim Acta 44:857-872

De Natale G, Troise C, Pingue F, De Gori P, Chiarabba C (2001) Structure and dynamics of the Somma-Vesuvius volcanic complex. Mineral Petrol 73:5-22

De Vivo B, Petrosino P, Lima A, Rolandi G, Belkin HE (2010) Research progress in volcanology in the Neapolitan area, Southern Italy: a review and alternative views. Mineral Petrol 99:1-28

Di Maio R, Mauriello P, Patella D, Petrillo Z, Piscitelli S, Siniscalchi A (1998) Electric and electromagnetic outline of the Mount SommaVesuvius structural setting. J Volcanol Geotherm Res 82:219-238

Di Renzo V, Di Vito MA, Arienzo I, Carandente A, Civetta L, D'Antonio M, Giordano G, Orsi G, Tonarini S (2007) Magmatic history of Somma-Vesuvius on the basis of new geochemical and isotopic data from a deep borehole (Camaldoli della Torre). J Petrol 48:753-784

Dolfi D, Trigila R (1978) The role of water in the 1944 Vesuvius eruption. Contrib Mineral Petrol 67:297-304

Droop GTR (1987) A general equation for estimating $\mathrm{Fe}^{3+}$ concentrations in ferromagnesian silicates and oxides from microprobe analyses, using stoichiometric criteria. Mineral Mag 51:431-435

Elkins LT, Grove TL (1990) Ternary feldspar experiments and thermodynamic models. Am Mineral 75:544-559

Fudali RF (1963) Experimental studies bearing on the origin of pseudoleucite and associated problems of alkalic rock genesis. Geol Soc Am Bull 74:1101-1126
Fulignati P, Marianelli P, Métrich N, Santacroce R, Sbrana A (2004) Towards a reconstruction of the magmatic feeding system of the 1944 eruption of Mt Vesuvius. J Volcanol Geotherm Res 133:13-22

Giaccio B, Isaia R, Fedele FG, Canzio D, Hoffecker J, Ronchitelli A, Sinitsyn A, Anikovich M, Lisitsyn SN (2008) The Campanian ignimbrite and Codola tephra layers; two temporal/ stratigraphic markers for the Early Upper Palaeolithic in southern Italy and eastern Europe. J Volcanol Geotherm Res 177:210-228

Gupta AK, Mauli Dwivedi M, Bhattachariya H, Dasgupta S (2010) Silica-undersaturated portion of the system nepheline-kalsilite$\mathrm{SiO}_{2}$ at $2 \mathrm{GPa}\left[P\left(\mathrm{H}_{2} \mathrm{O}=P(\right.\right.$ total $\left.)\right]$. Can Mineral 48:1297-1313

Hamilton DL, MacKenzie WS (1965) Phase equilibrium studies in the system $\mathrm{NaAlSiO}_{4}$ (nepheline) $-\mathrm{KAlSiO}_{4}$ (kalsilite) $-\mathrm{SiO}_{2}-\mathrm{H}_{2} \mathrm{O}$. Mineral Mag 34:214-231

Henderson CMB, Richardson FR, Charnock JM (2012) The Highwood Mountains potassic igneous province, Montana: mineral fractionation trends and magmatic processes revisited. Mineral Mag 76: $1005-1051$

Ippolito F, D'Argenio B, Pescatore T, Scandone P (1975) Structural stratigraphic units and tectonic framework of southern Appenines. In: Squyres CH (ed) Geology of Italy 2: 317-328

Jolis EM, Freda C, Troll VR, Deegan FM, Blythe IS, McLeod CL, Davidson JF (2013) Experimental simulation of magma-carbonate interaction beneath Mt. Vesuvius, Italy. Contrib Mineral Petrol 166: $1335-1353$

Joron JL, Métrich N, Rosi M, Santacroce R, Sbrana A (1987) Chemistry and petrology. In: Santacroce R (ed) Somma Vesuvius. CNR Quad. Ric. Sci. 114:105-174

Landi P, Bertagnini A, Rosi M (1999) Chemical zoning and crystallization mechanisms in the magma chamber of the Pomici di Base plinian eruption of Somma-Vesuvius (Italy). Contrib Mineral Petrol 135:179-197

Le Bas MJ, Le Maitre RW, Streickesen A, Zanettin B (1986) A chemical classification of volcanic rocks based on the total alkali-silica diagram. J Petrol 27:745-750

Lima A, Belkin HE, Török K (1999) Understanding Vesuvius magmatic processes: evidence from primitive silicate-melt inclusions (Terzigno Formation). Mineral Petrol 65:185-206

Lima A, Danyushevsky LV, De Vivo B, Fedele L (2003) A model for the evolution of the Mt. Somma-Vesuvius magmatic system based on fluid and melt inclusion investigations. In: De Vivo B (ed) Melt inclusions in volcanic systems. Methods, applications and problems. Elsevier, Amsterdam, Developments in Volcanology 5:227-249

Macdonald R, Bagiński B, Dzierżanowski P, Jokubauskas P (2013) Apatite-supergroup minerals in UK Palaeogene granites: composition and relationship to host-rock composition. Eur J Mineral 25: 461-471

Marianelli P, Métrich N, Santacroce R, Sbrana A (1995) Mafic magma batches at Vesuvius: a glass inclusion approach to the modalities of feeding stratovolcanoes. Contrib Mineral Petrol 120:159-169

Marianelli P, Métrich N, Sbrana A (1999) Shallow and deep reservoirs involved in magma supply of the 1944 eruption of Vesuvius. Bull Volcanol 61:48-63

Marianelli P, Sbrana A, Métrich N, Cecchetti A (2005) The deep feeding system of Vesuvius involved in recent violent strombolian eruptions. Geophys Res Lett 32, L02306. doi:10.1029/2004GL021667

Morimoto N (1988) Nomenclature of pyroxenes. Mineral Mag 52: $535-550$

Nag K, Arima M, Gupta AK (2007) Experimental study of the joins forsterite-diopside-leucite- and forsterite-leucite-åkermanite up to $2.3 \mathrm{GPa}\left[\left(P\left(\mathrm{H}_{2} \mathrm{O}\right)=P(\right.\right.$ Total $\left.)\right]$ and variable temperatures: Its petrological significance. Lithos 98:177-194

Pichavant M, Scaillet B, Pommier A, Lacono-Marziano G, Cioni R (2014) Nature and evolution of primitive Vesuvius magmas: an experimental study. J Petrol 55:2281-2310 
Piochi M, Ayuso RA, De Vivo B, Somma R (2006) Crustal contamination and crystal entrapment during polybaric magma evolution at Mt. Somma-Vesuvius volcano, Italy: Geochemical and $\mathrm{Sr}$ isotope evidence. Lithos 86:303-329

Pouchou JL, Pichoir JF (1991) Quantitative analysis of homogeneous or stratified microvolumes applying the model 'PAP'. In: Newbury H (ed) Electron probe quantitation. Plenum Press, New York, pp 31-75

Raia F, Webster JD, De Vivo B (2000) Pre-eruptive volatile contents of Vesuvius magmas: constraints on eruptive history and behaviour. IThe medieval and modern interplinian activities. Eur J Mineral 12: 179-193

Rolandi G, Petrosino P, McGeehin J (1998) The interplinian activity at Somma-Vesuvius in the last 3500 years. J Volcanol Geotherm Res $82: 19-52$

Santacroce R (ed) (1987) Somma-Vesuvius. CNR Quad. Ric. Sci: 114, $251 \mathrm{pp}$

Santacroce R, Bertagnini A, Civetta L, Landi P, Sbrana A (1993) Eruptive dynamics and petrogenetic processes in a very shallow magma reservoir: the 1906 eruption of Vesuvius. J Petrol 34:383-425

Santacroce R, Sbrana A (2003) Geological map of Vesuvius 1:15,000 scale. SELCA, Firenze

Santacroce R, Cioni R, Marianelli P, Sbrana A, Sulpizio R, Zanchetta G, Donahue DJ, Joron JL (2008) Age and whole-rock-glass compositions of proximal pyroclastics from the major explosive eruptions of Somma-Vesuvius: a review as a tool for distal tephrostratigraphy. J Volcanol Geotherm Res 177:1-18

Scaillet B, Pichavant M, Cioni R (2008) Upward migration of Vesuvius magma chamber over the past 20,000 years. Nature 455:216-220

Schettino A, Turco E (2006) Plate kinematics of the Western Mediterranean region during the Oligocene and early Miocene. Geophys J Int 166:1398-1423

Sun S-S, McDonough, WF (1989) Chemical and isotopic systematics of oceanic basalts: implications for mantle composition and processes. In Saunders AD, Norry MJ (eds) Magmatism in the Ocean Basins. Geol Soc Spec Pub 42:313-345

Villemant B, Trigila R, De Vivo B (1993) Geochemistry of Vesuvius volcanics during 1631-1944 period. J Volcanol Geotherm Res 58: 291-313

Zeng R, MacKenzie WS (1984) Phase diagrams for the system leucite$\mathrm{H}_{2} \mathrm{O}$ at 2 and $5 \mathrm{~kb}$. Progress on experimental petrology, sixth report. NERC Publ Ser D25:25-27

Zollo A, Gasparini P, Virieux J, Biella G, Boschi E, Capuano P, Franco R, Dell'Aversana P, Matteis R, Natale G, Iannaccone G, Guerra I, Le Meu H, Mirabile L (1998) An image of Mt. Vesuvius obtained by 3D seismic tomography. J Volcanol Geotherm Res 82:161-173 